\title{
Dispersal and emerging ecological impacts of Ponto-Caspian species in the Laurentian Great Lakes $^{1}$
}

\author{
Henry A. Vanderploeg, Thomas F. Nalepa, David J . J ude, Edward L. Mills, \\ Kristen T. Holeck, J ames R. Liebig, Igor A. Grigorovich, and Henn Ojaveer
}

\begin{abstract}
We describe, explain, and "predict" dispersal and ecosystem impacts of six Ponto-Caspian endemic species that recently invaded the Great Lakes via ballast water. The zebra mussel, Dreissena polymorpha, and quagga mussel, Dreissena bugensis, continue to colonize hard and soft substrates of the Great Lakes and are changing ecosystem function through mechanisms of ecosystem engineering (increased water clarity and reef building), fouling native mussels, high particle filtration rate with selective rejection of colonial cyanobacteria in pseudofeces, alteration of nutrient ratios, and facilitation of the rapid spread of their Ponto-Caspian associates, the benthic amphipod Echinogammarus ischnus and the round goby, Neogobius melanostomus, which feeds on zebra mussels. The tubenose goby, Proterorhinus marmoratus, which does not feed on zebra mussels, has not spread rapidly. Impacts of these benthic invaders vary with site: in some shallow areas, habitat changes and the Dreissena $\rightarrow$ round goby $\rightarrow$ piscivore food chain have improved conditions for certain native game fishes and waterfowl; in offshore waters, Dreissena is competing for settling algae with the native amphipod Diporeia spp., which are disappearing to the detriment of the native deep-water fish community. The predatory cladoceran Cercopagis pengoi may compete with small fishes for zooplankton and increase food-chain length.
\end{abstract}

Résumé : Notre travail décrit et explique la dispersion de six espèces endémiques de la région pontocaspienne qui ont récemment envahi les Grands-Lacs via l'eau de ballastage, ainsi que leur impact sur l'écosystème; nous formulons aussi des prédictions. La moule zébrée, Dreissena polymorpha, et la moule quagga, Dreissena bugensis, continuent de coloniser les substrats durs et mous des Grands-Lacs et de modifier le fonctionnement de l'écosystème par des transformations physiques du biotope (accroissement de la transparence de l'eau et construction de récifs), par l'encrassement des moules indigènes, par un taux élevé de filtration de particules et un rejet sélectif des colonies de cyanobactéries dans leurs pseudofèces, par la perturbation des rapports des nutriments et par la facilitation de la dispersion rapide d'espèces associées également d'origine pontocaspienne, l'amphipode benthique Echinogammarus ischnus et le gobie à taches noires, Neogobius melanostomus, qui se nourrit de moules zébrées. Le gobie à nez tubulaire, Proterorhinus marmoratus, qui ne se nourrit pas de moules zébrées, a une dispersion moins rapide. L'impact de ces espèces envahissantes varie d'un site à un autre; dans quelques régions d'eau peu profonde, les modifications de l'habitat et la chaîne alimentaire Dreissena $\rightarrow$ gobie à taches noires $\rightarrow$ piscivores améliorent les conditions d'existence de certains poissons indigènes d'intérêt sportif et celles de la sauvagine; dans les eaux du large, Dreissena entre en compétition pour les algues en sédimentation avec les amphipodes indigènes Diporeia spp., qui sont en voie de disparition, et cela au détriment de la communauté de poissons indigènes d'eau profonde. Le cladocère prédateur Cercopagis pengoi entre peut-être en compétition avec les petits poissons pour le zooplancton et allonge ainsi la chaîne alimentaire.

[Traduit par la Rédaction]

Received 21 November 2000. Accepted 27 March 2002. Published on the NRC Research Press Web site at http://cjfas.nrc.ca on 13 August 2002.

J16093

H.A. Vanderploeg, ${ }^{2}$ T.F. Nalepa, and J.R. Liebig. Great Lakes Environmental Research Laboratory, NOAA, 2205 Commonwealth Boulevard, Ann Arbor, MI 48105, U.S.A.

D.J. Jude. Center for Great Lakes and Aquatic Sciences, 501 East University Drive, University of Michigan, Ann Arbor, MI 48109-1090, U.S.A.

E.L. Mills and K.T. Holeck. Cornell Biological Field Station, 900 Shackelton Point Road, Bridgeport, NY 13030, U.S.A. I.A. Grigorovich. Great Lakes Institute for Environmental Research, University of Windsor, Windsor, ON N9B 3P4, Canada. Henn Ojaveer. Estonian Marine Institute, Viljandi Rd. 18 , 11216 Tallinn, Estonia.

${ }^{1}$ From the series "Biological invasions of aquatic habitats in Europe and the Great Lakes".

${ }^{2}$ Corresponding author (e-mail: Henry.Vanderploeg@noaa.gov). 


\section{Introduction}

The Great Lakes ecosystem is a system of five large lakes and connecting waterways that provide diverse benthic and pelagic habitats for a variety of indigenous and nonindigenous species. Several Ponto-Caspian endemics have recently invaded the Great Lakes: the zebra mussel, Dreissena polymorpha; the quagga mussel, Dreissena bugensis; the predatory cladoceran Cercopagis pengoi; the benthic amphipod Echinogammarus ischnus; the round goby, Neogobius melanostomus; and the tubenose goby, Proterorhinus marmoratus. All these euryhaline species arrived in ballast water (Ricciardi and Rasmussen 1998; Makarewicz et al. 2001).

The Great Lakes have undergone and continue to undergo profound ecological changes in response to Ponto-Caspian invaders. Because the Great Lakes are currently undergoing changes resulting from oligotrophication, piscivorous fish stocking, and other exotic species introductions (Mills et al. 1993), impacts of Ponto-Caspian invaders are acting in concert with these other anthropogenic changes. Thus, it is not enough to document changes in the system since invasion and attribute them to the invaders, but it is also necessary to relate-ideally quantitatively_the changes through a set of plausible underlying mechanisms to these recent invaders to define relative contributions of all factors.

The purpose of this paper is to review dispersal patterns and ecological impacts associated with each invading PontoCaspian species in the Great Lakes. We start with a synthesis of the ecology of each Ponto-Caspian invader and of mechanisms by which they spread and affect ecosystems as derived from studies in the laboratory, the Great Lakes, and other systems. Information derived from the ecological synthesis is applied to areas in the Great Lakes where the ecosystem has been monitored to generate case studies of invaderinduced change, the underlying causes, and predictions for the future that are holistic as possible. This exercise is extremely important not only for impact description but also, when synthesized, for revealing mechanisms and interactions not suspected from prior knowledge of each invader alone or from current understanding of aquatic ecosystem processes and Great Lakes ecology. The paper closes with the lessons learned from this synthesis that have relevance to understanding invasion ecology, aquatic ecosystem function, and Great Lakes food webs. We show that although dispersal patterns of these Ponto-Caspian invaders in the Great Lakes have some similarity to patterns seen in Eurasia, extrapolations of impact from Eurasia have limited value.

\section{Dispersal and ecology}

\section{Zebra mussel, the first dreissenid invader}

The first sighting of zebra mussels in the Great Lakes was in the Canadian waters of Lake St. Clair in June 1988 (New York Sea Grant 2002). By September 1990, D. polymorpha had dispersed rapidly and was found in all of the Great Lakes. In the following year, zebra mussels were found outside the Great Lakes basin in the Illinois and Hudson rivers. After 1992, populations of zebra mussels spread rapidly throughout the eastern United States and parts of Canada (New York Sea Grant 2002).

\section{An r strategist invading a new environment}

The zebra mussel is physiologically suited for growth and reproduction in all of the Great Lakes except open Lake Superior, where the calcium concentration of $12 \mathrm{mg} \cdot \mathrm{L}^{-1}$ is below the $15 \mathrm{mg} \cdot \mathrm{L}^{-1}$ threshold necessary for survival; moreover, Lake Superior temperatures are seldom above $12^{\circ} \mathrm{C}$, the temperature required for gonadal growth and spawning (Melina and Rasmussen 1994). The zebra mussel invaded an empty niche in the Great Lakes, colonizing a wide range of benthic (rock, shells, sand grains) and littoral (macrophytes) substrates. Unlike native mussels, zebra mussels are $r$ strategists (species having life-history characteristics promoting rapid population growth, $r$; MacArthur and Wilson 1967), producing numerous planktonic larvae and reaching sexual maturity within 1 year (Garton and Haag 1992).

\section{High filtering rate, the foundation of the $\mathbf{r}$ strategy}

Dreissena polymorpha, because of its high filter area per unit mass (Kryger and Riisgård 1988) and small size, has an intrinsically high filtering (clearance) rate that is $\sim 10$ times that of unionid mussels (Fig. 1a). Like unionid mussels, zebra mussels can filter a broad size range of particles $(\sim 1 \mu \mathrm{m}-750 \mu \mathrm{m}$; Vanderploeg et al. 1995, 2001). The high filtering rate and broad size range of particles ingested is an important aspect of the $r$ strategy that allows zebra mussels to ingest great quantities of seston and have high reproductive output and high population growth rates. Zebra mussels, under high food concentrations of easily assimilated algae, can ingest and assimilate up to approximately $40 \%$ of their body carbon per day (Vanderploeg et al. 2001).

\section{Linkages between feces, pseudofeces, and food selection}

The composition and quantity of pseudofeces and feces produced by dreissenids have important ecosystem consequences (Fig. 2). Feces and pseudofeces in shallow systems or nearshore habitats represent an energy flux to the benthos, especially for deposit-feeding benthos that are associated with zebra mussels and can utilize feces. Sorting of unwanted particles into pseudofeces is far from perfect, especially in the case of suspended sediment, and some of these particles are ingested and end up in feces (Roditi et al. 1997). Pseudofeces containing clay or algae can be quite fragile (Roditi et al. 1997; Vanderploeg et al. 2001). They are easily resuspended, like feces, especially under turbulent mixing that occurs in estuaries (e.g., Hudson River; Roditi et al. 1997) and large, shallow basins of the Great Lakes (e.g., Saginaw Bay and western Lake Erie; Vanderploeg et al. 2001). Because mussels do not assimilate clay and other inorganic particles, these particles can be returned to the water column; thus, in systems dominated by inorganic particles, dreissenids may only have a modest impact on water clarity (Roditi et al. 1997). Feces and pseudofeces may be transported to deep areas as the result of resuspension and the action of currents (Fig. 2), thus leading to impacts some distance away from the mussels.

It is possible that selective feeding by zebra mussels is an important selective force favoring dominance of the algal community by colonial cyanobacteria during summer (e.g., 
Fig. 1. The dominance of zebra mussels in aquatic systems illustrated by their high clearance rates compared with those of native mussels $(a)$ and high biomass compared with that of zooplankton $(b)$. (a) Weight-specific clearance rate $(F / W)$ at $20^{\circ} \mathrm{C}$ as a function of dry flesh weight $(W)$ in Dreissena polymorpha $(D p)$, four European species of unionid mussels (Kryger and Riisgård 1988), and one North American unionid species (Vanderploeg et al. 1995) under ideal feeding conditions in the laboratory. The European mussels are Anodonta anatina $(A a)$, Unio crassus $(U c)$, U. pictorum $(U p)$, and U. tumidus (Ut), and the North American mussel is Lampsilis radiata siliquoidea (Lrs). (b) Zebra mussel biomass concentration per unit water volume (g dry weight (DW) $\mathrm{m}^{-3}$ ) vs. total phosphorous concentration, TP $\left(\mathrm{mg} \cdot \mathrm{m}^{-3}\right)$, for zebra mussels in Polish and North American lakes compared with the regression line of Hanson and Peters (1984) for crustacean zooplankton in lakes. Dreissena data, except for Saginaw Bay, come from Polish and North American lakes reported by Wilson and Sarnelle (2002). Symbols: Saginaw Bay $(\boldsymbol{\Delta})$, Lake Ontario $(\boldsymbol{O})$, western basin of Lake Erie $(\bullet)$, eastern basin of Lake Erie $(\boldsymbol{\square})$, Lake St. Clair $(\times)$, and Polish lakes $(\bigcirc)$.
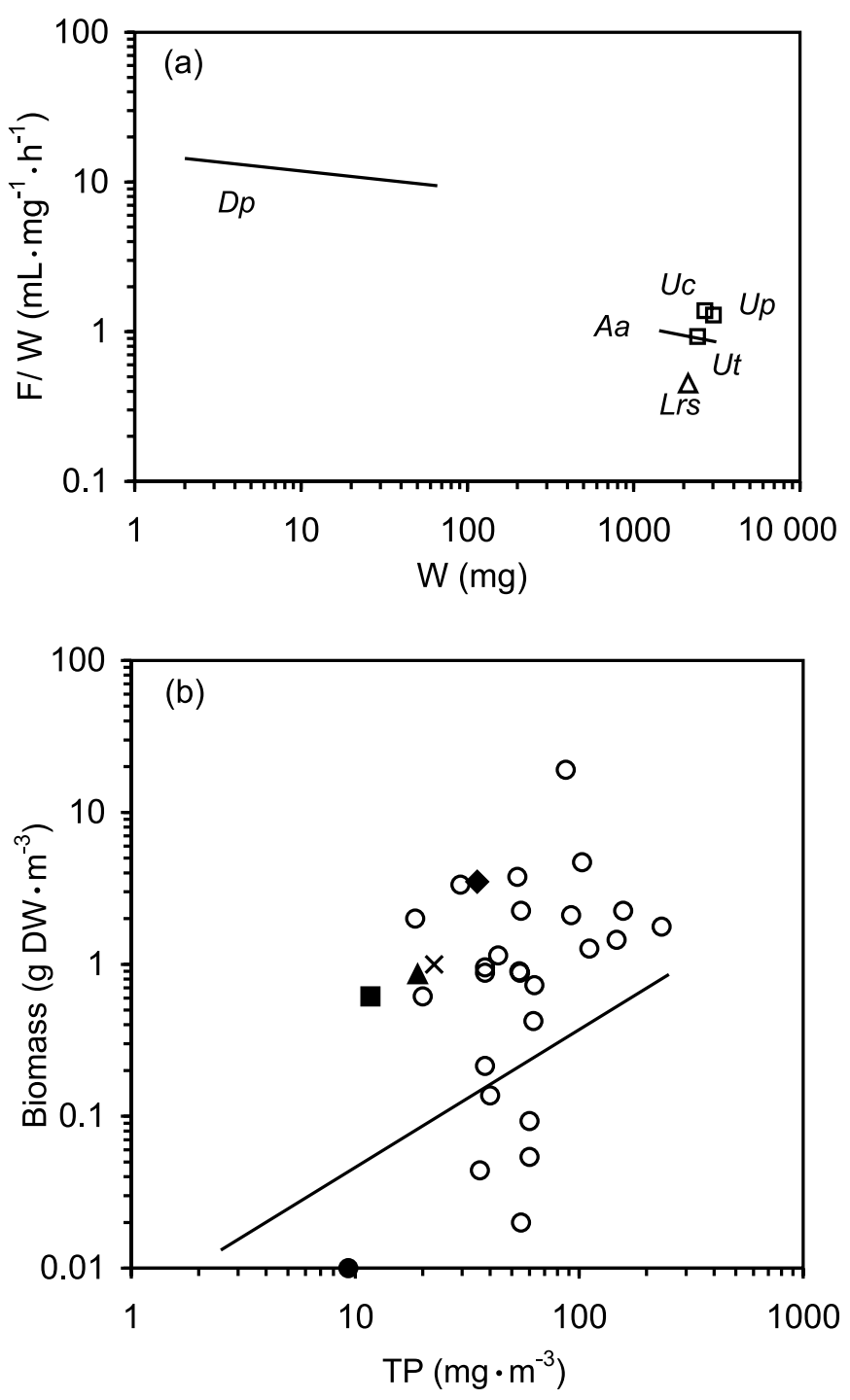

Fig. 2. Interactions of zebra mussels occurring in a hypothetical shallow system, such as Saginaw Bay (Lake Huron), with other ecosystem components via the mechanisms of mussel feeding, nutrient excretion, and ecosystem engineering (habitat modification). The solid lines indicate material flow (carbon, nutrients, and sediments), and broken lines indicate engineering effects.

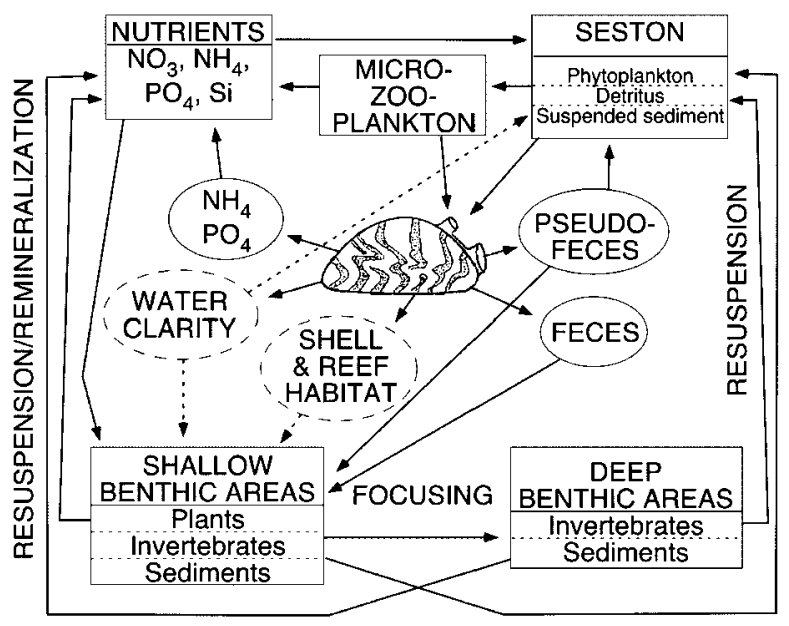

Vanderploeg et al. 2001). Selective rejection of Microcystis (observed in pseudofeces) by zebra mussels may have promoted toxic Microcystis blooms in Lake Erie and Saginaw Bay (Lake Huron). Dreissena took in all algae, but small edible algae were ingested, whereas Microcystis was returned unharmed to the water column in pseudofeces (Vanderploeg et al. 2001). Given high water column clearance rates of mussels in some systems (see below), selective feeding could be an important force not only for promoting Microcystis dominance, but also for other grazing-resistant (large or digestion-resistant) species as well (Vanderploeg et al. 2001). The algal community response to mussel grazing may also include selection for rapidly growing species (Vanderploeg et al. 2001).

\section{Dreissenid biomass and potential filtering impact}

The prediction of mussel impacts on ecological variables such as nutrient cycling and energy flow requires knowledge of biomass concentration and aggregate filtering rate of mussels in nature. Filtering rate in nature can be estimated from relationships developed for mussel dry weight (Fig. 1a), mussel length, and filter surface area (a function of mussel length) along with natural biomass densities or mussel numbers and lengths (Kryger and Riisgård 1988).

Dreissenids can attain high densities in aquatic systems. Biomass values for dreissenids in the Great Lakes vary depending on the habitat (Table 1), and these values are consistent with biomass expected for total phosphorus concentrations of these lakes (Wilson and Sarnelle 2002). Biomass of mussels is 2052 times higher than crustacean zooplankton, the other major group of metazoan consumers of phytoplankton, in shallow $(<25 \mathrm{~m})$ basins of the Great Lakes (Table 1). The generalization of much higher concentrations of Dreissena relative to zooplankton can be appreciated from a plot of mussel biomass vs. total phosphorus (TP) concentration compared to the expected zooplankton biomass (Fig. 1b) 
Table 1. Biomass expressed as dry weight (DW) of dreissenids (soft tissue) and zooplankton and fraction of water column cleared (FC) by dreissenids in different bays and basins of the Great Lakes.

\begin{tabular}{|c|c|c|c|c|c|c|}
\hline \multirow[b]{2}{*}{ Lake } & \multirow[b]{2}{*}{ Year invaded } & \multirow[b]{2}{*}{ Year sampled } & \multirow[b]{2}{*}{ Mean depth (m) } & \multicolumn{2}{|c|}{ Biomass $\left(\mathrm{g} \mathrm{DW} \cdot \mathrm{m}^{-2}\right)$} & \multirow[b]{2}{*}{$\mathrm{FC}^{a}\left(\right.$ day $\left.^{-1}\right)$} \\
\hline & & & & Dreissenids & Zooplankton & \\
\hline Erie (western basin) & 1988 & $1992-1993$ & 7.4 & $26.2^{b}$ & $0.50^{f}$ & 0.994 \\
\hline Ontario (whole lake) & 1990 & 1995 & 86.0 & $0.9^{c}$ & & 0.003 \\
\hline Saginaw Bay & 1991 & 1993-1996 & 5.1 & $5.0^{d}$ & $<0.25^{g}$ & 0.275 \\
\hline St. Clair & 1986 & 1990-1994 & 3.1 & $3.8^{e}$ & & 0.344 \\
\hline
\end{tabular}

${ }^{a}$ Filtering rate assumed to be $11.7 \mathrm{~L} \cdot \mathrm{g} \mathrm{DW} \cdot \mathrm{h}^{-1}$ (Kryger and Riisgård 1988).

${ }^{b}$ From total wet biomass (including shell) data of Custer and Custer (1997) and Johannsson et al. (2000) weighted by depth and sediment type and converted to dry flesh biomass by using a conversion factor of 0.03 (A.E. Wilson, Georgia Institute of Technology, Atlanta, GA 30066, and O. Sarnelle, Michigan State University, East Lansing, MI 48824, unpublished data).

${ }^{c}$ Wilson and Sarnelle (2002).

${ }^{d}$ Mean biomass for equilibrium biomass years 1993-1996 (see Fig. 6).

${ }^{e}$ Nalepa et al. (1996b).

${ }^{f}$ Crustaceans and rotifers (Dahl et al. 1995).

${ }^{g}$ Crustacean zooplankton (Bridgeman et al. 1995; H.A. Vanderploeg, unpublished data).

based on the regression of Hanson and Peters (1984). Thus, in shallow lakes and areas of the Great Lakes, dreissenids can be dominant consumers of phytoplankton, compete with zooplankton, and dominate pelagic nutrient cycling. Part of the reason for their high biomass under most circumstances may be due to low predation pressure on settled mussels (see below) relative to zooplankton, which are preyed upon by a variety of pelagic fishes and invertebrates. In addition, Dreissena larvae are vulnerable to predation by a variety of omnivorous or predatory zooplankton only before they form their larval bivalve shell a few days after hatching (Liebig and Vanderploeg 1995).

There has been rapid colonization of zebra mussels on hard substrates in the Great Lakes followed by slower colonization on softer substrates (e.g., Bially and MacIsaac 2000; Nalepa et al. 2001). Zebra mussel distribution on soft sediments can be affected by wave action and depth-related production. The high concentrations of zebra mussels on sandy substrates on the eastern side of Lake Michigan between $15 \mathrm{~m}$ and $30 \mathrm{~m}$ and expanding populations between $30 \mathrm{~m}$ and $50 \mathrm{~m}$ (Nalepa et al. 2001) benefit from low wave energy and the deep chlorophyll layer that intersects the bottom at these depths.

The magnitude of the mussel filtering impact on the plankton mortality rate in a well-mixed water column may be expressed as the fraction of the water column cleared per unit time (FC). FC in well-mixed systems is directly proportional to mussel biomass expressed on an areal basis ( $\mathrm{g}$ dry weight $(\mathrm{DW}) \cdot \mathrm{m}^{-2}$ ) and inversely proportional to water column depth. Because of the inverse relation of FC with water column depth, zebra mussel impacts on pelagic systems occur predominantly in shallow well-mixed basins or are restricted to nearshore areas of the deep basins. Under typical nutrientlimiting conditions, algal growth rate is $0.2-0.5 \mathrm{day}^{-1}$, whereas growth rate is $\sim 1-2$ day $^{-1}$ when nutrients are not limiting (e.g., Fahnenstiel et al. 1995; Vanderploeg et al. 2001). FC approaching algal growth rates, as they do in some Great Lakes basins (Table 1), will result in substantial algal mortality and lowered phytoplankton concentration and primary production. This generalization also applies to microzooplankton, such as protozoa and rotifers (Lavrentyev et al. 1995; MacIsaac et al. 1995), which are filtered and ingested by zebra mussels. Microzooplankton are doubly affected: they suffer direct mortality from mussel grazing as well as loss of food resources.

After invasion by zebra mussel, some crustacean zooplankton populations have decreased (e.g., Karatayev et al. 1997; Pace et al. 1998). However, in most eutrophic or mesotrophic lakes studied in North America, only small or modest declines in crustacean zooplankton have been observed (Dahl et al. 1995; Mayer et al. 2000; Beeton and Hageman 2000). In Oneida Lake, algal biomass declined in response to Dreissena, but Daphnia spp. biomass and production did not (Idrisi et al. 2001). In contrast to crustacean zooplankton, large decreases in microzooplankton (e.g., rotifers and protozoa) have been documented in Great Lakes waters (Lavrentyev et al. 1995; Dahl et al. 1995; Beeton and Hageman 2000).

\section{Zebra mussels and nutrient cycling}

The relatively limited amount of work examining both phosphorus $(\mathrm{P})$ and nitrogen $(\mathrm{N})$ cycling by zebra mussels suggests that dreissenids play an important role and have ecosystem-level consequences (Stañczykowska and Planter 1985; Johengen et al. 1995; Arnott and Vanni 1996). N, P, and silicon ( $\mathrm{Si}$ ) associated with seston (including microzooplankton) are ingested by Dreissena (Fig. 2). Some of the ingested $\mathrm{P}$ and $\mathrm{N}$ is assimilated and retained at relatively constant concentrations in mussel tissues (T. Johengen, Center for Limnology and Ecosystem Research, University of Michigan, Ann Arbor, MI 48105, and H. Vanderploeg, unpublished data), and some $\mathrm{N}$ and $\mathrm{P}$ are excreted as $\mathrm{NH}_{4}$ and $\mathrm{PO}_{4}$, which return to the soluble nutrient pool available for uptake by phytoplankton and benthic plants (Fig. 2). Silica and unassimilated $\mathrm{N}$ and $\mathrm{P}$ are egested as feces and may become part of the sediment pool near the mussels; however, feces can be suspended in turbulent systems and return nutrients to the seston or be transported and settle in areas away from the mussels (Fig. 2). Pseudofeces could possibly remove nutrients from the water column; however, turbulence would return some of the live algae or other seston within pseudofeces to the water column (Roditi et al. 1997).

Dreissenids may affect nutrient availability, which in turn could affect algal composition. When seston N:P ratios are 
low relative to the Redfield ratio, $\mathrm{N}$ is limiting and cyanobacteria are at a competitive advantage over other algal groups (Smith 1982). Like zooplankton, which have been identified as important regulators of $\mathrm{N}$ and $\mathrm{P}$ (Sterner et al. 1992), mussels may appreciably affect $\mathrm{N}: \mathrm{P}$ of soluble nutrients by homeostatically maintaining constant nutrient concentrations in their tissues. Thus, Dreissena could increase $\mathrm{P}$ limitation when $\mathrm{P}$ is limiting and increase $\mathrm{P}$ availability when it is not. Because mussels can achieve high densities and have a much greater grazing impact than crustacean zooplankton, this N:P skewing could be very important. There is evidence for this skewing in P-poor Saginaw Bay and P-rich western Lake Erie (see below). It is theoretically possible that the low $\mathrm{N}: \mathrm{P}$ of $\mathrm{NH}_{4}$ and $\mathrm{PO}_{4}$ excreted by mussels in Lake Erie could favor succession of cyanophytes over other algal groups (Arnott and Vanni 1996).

\section{The role of zebra mussels in modifying habitats through physical ecosystem engineering}

In addition to being part of the food web and directly participating in nutrient cycling, organisms can modify or create habitats for other species by causing physical state changes in biotic or abiotic materials (Jones et al. 1997). Effects of zebra mussel ecosystem engineering on shallow water food webs of the Great Lakes (Fig. 3) demonstrate large habitat modifications, and these changes alone qualify zebra mussels as a keystone species. Zebra mussels act as autogenic engineers by producing their own physical structures, i.e., their shells (Figs. 2 and 3). These shells provide solid surfaces for attachment of algae and spatially complex surfaces for the benefit amphipods, turbellarians, hydrozoans, and oligochaetes, while certain chironomids and gastropods benefit from both habitat structure and food supply (Stewart et al. 1998; Bially and MacIsaac 2000). The native amphipod Gammarus and the Ponto-Caspian invading amphipod Echinogammarus, in particular, have benefited from zebra mussels (Stewart et al. 1998; Bially and MacIsaac 2000). In the Ponto-Caspian region, Echinogammarus and zebra mussels are common community associates; therefore, zebra mussels, by producing substrate for Echinogammarus, have facilitated their expansion in the Great Lakes (Ricciardi 2001).

The zebra mussel acts as an allogenic ecosystem engineer by increasing water clarity by removing particles from the water column (Fig 2). This has profound consequences for benthic algae and macrophytes (Fig. 3), which are usually light-limited (Lowe and Pillsbury 1995). A decrease in turbidity in shallow systems by increased grazing pressure can shift a turbid, plankton-dominated system to one dominated by macrophytes (Scheffer 1989; Reeders and Bij de Vaate 1990). Once macrophytes become established, they too act as ecosystem engineers to further reduce turbidity by preventing resuspension through their stabilizing effect on the sediments. As their biomass increases, macrophytes play a larger role in nutrient cycling and compete with phytoplankton for nutrients. Moreover, macrophytes can become substrate for the mussels, promoting still further increases in water clarity. Increased water clarity also increases visibility of prey to visual predators such as fishes and waterfowl (Petrie and Knapton 1999; Mayer et al. 2000). Increased water clarity can lead to a shift from fish species preferring turbid conditions, such as the walleye (Stizostedion vitreum), to
Fig. 3. Food-web and ecosystem-engineering mechanisms of impact of the Ponto-Caspian benthic assemblage (Dreissena, Neogobius, and Echinogammarus), or meltdown assemblage, in bays, interconnecting waterways, and nearshore areas of the Great Lakes. Solid arrows indicate food-web connections. The dashed double arrow indicates potential competitive interactions, and the dotted arrows indicate the influence of ecosystem engineering through the mechanisms of habitat provision (autogenic engineering) and water clarity (allogenic ecosystem engineering). WC is placed next to solid arrows for predation by vertebrate (visual) predators (fishes and waterfowl) to indicate possible increases in predation rate associated with increased water clarity.

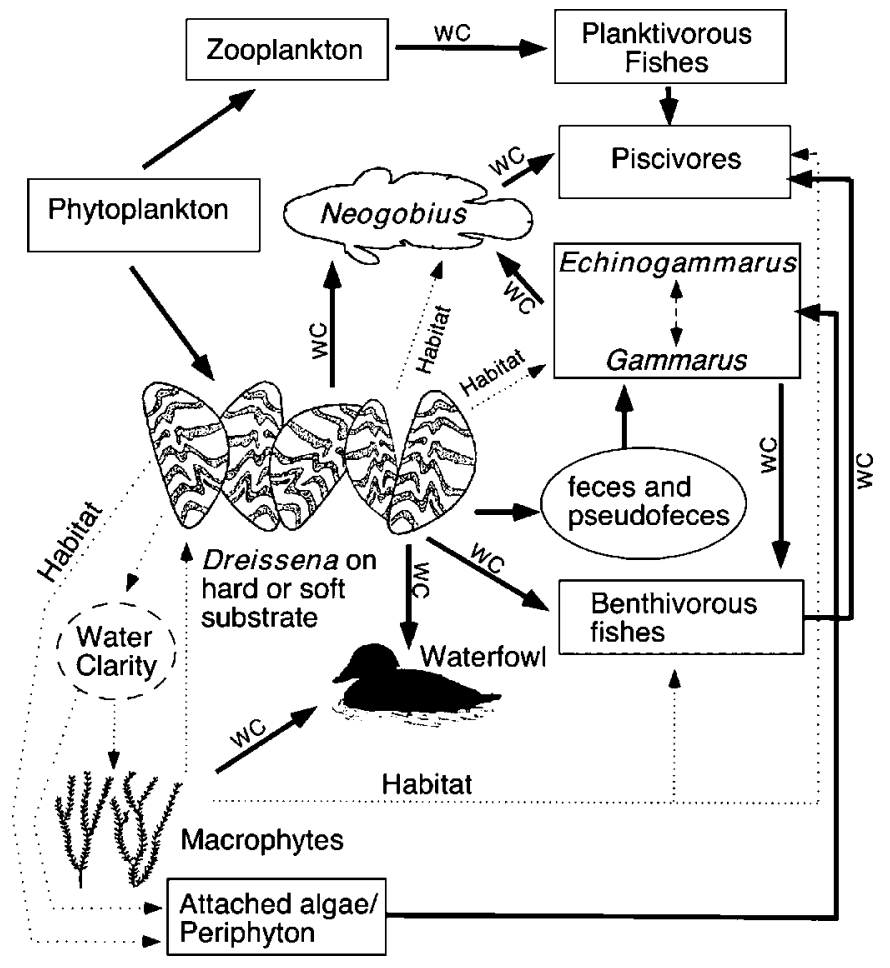

fishes preferring clear water, such as muskellunge (Esox masquinongy) and smallmouth bass (Micropterus dolimieu), which can use macrophytes as cover or spawning habitat (see below and Ryan et al. 1999).

\section{Zebra mussels fouling native unionid shells-intimate interference}

Unionid mussels are active from spring through fall, partially buried with their siphons sticking above the sedimentwater interface. During this time, the exposed portion of the shell becomes a substrate for settling zebra mussel larvae (Schloesser et al. 1996). As zebra mussels increase in number and grow on unionid shells, they can impact these mollusks by deforming and preventing proper closure of the host's valves, making it difficult to maintain position at the sediment-water interface and interfering with feeding by occluding the siphons (Schloesser et al. 1996). Extirpation of native unionids typically occurred in both very soft and sandy substrates (Schloesser et al. 1996) in the Great Lakes and most other environments 4-8 years after zebra mussel density had achieved high levels $\left(10^{3}-10^{5}\right.$ mussels $\cdot \mathrm{m}^{-2}$, Ricciardi et al. 1998), except for marshes (Nichols and 
Wilcox 1997) and very shallow areas of open coasts (Schloesser et al. 1997), which act as refuges for native mussels. Strayer (1999) noted that in the Hudson River, exploitative competition for suspended algae might have been an important factor in reducing unionids because unionids had low infestation rates for attached zebra mussels. Thus both fouling and reduction of food resources may be important factors in the unionid decline.

\section{Quagga mussel-extending Dreissena and its impacts into deep water}

Quagga mussels were first sighted in northeastern Lake Erie (Port Colborne, Ontario) in 1989 (Mills et al. 1999). By 1993, the distribution extended from Lake St. Clair eastward to Quebec City on the St. Lawrence River. Studies in 1995 indicated that the quagga mussel was the dominant dreissenid in the eastern basin of Lake Erie and was the most abundant dreissenid in areas of Lake Ontario where zebra mussel was once dominant-a trend that paralleled population changes in the Dnieper River basin in the Ukraine (Mills et al. 1996, 1999). In 1997, D. bugensis was found in northern Lake Huron and in 2001 at many sites in Lake Michigan (Nalepa et al. 2001; New York Sea Grant 2002).

In Lakes Erie and Ontario, zebra mussels are largely restricted to substrates in the nearshore $(<30 \mathrm{~m})$, epilimnetic waters of the Great Lakes (Claxton et al. 1998; Dermott et al. 1998a; Mills et al. 1999). Two phenotypes of D. bugensis have now been reported in the Great Lakes: the "epilimnetic" form, which has a high flat shell and competes with zebra mussels in epilimnetic waters, and the "profunda" form, which has an elongate modioliform shell and has invaded soft sediments in the hypolimnion (Claxton et al. 1998; Dermott et al. 1998a; Mills et al. 1999). The epilimnetic form, like the zebra mussel, uses its byssal threads to attach to objects and particles and form druses or colonies. The profunda morph can form colonies and attach to objects with its byssal threads or it can partially bury itself in soft sediments and extend its very long incurrent siphon above itself to bring in suspended food particles. The quagga mussel has been found to produce mature oocytes and spawn in the hypolimnion, which implies it has a lower temperature limit for gonadal growth and spawning than the zebra mussel (Roe and MacIsaac 1997). The lower temperature tolerance of the quagga means that all of the Great Lakes could be colonized by dreissenids except for Lake Superior, where calcium levels are probably limiting.

That $D$. bugensis is able to grow and produce gametes in the hypolimnion suggests it may out-compete $D$. polymorpha in shallow waters during cooler months. It remains to be seen how well these two species filter and assimilate algae during winter and early spring. Although food concentration is low (chlorophyll $a \approx 1 \mu \mathrm{g} \cdot \mathrm{L}^{-1}$ ) during winter and early spring in the Great Lakes, nutritional quality in terms of $\mathrm{P}$ and polyunsaturated fatty acid (PUFA) concentrations is expected to be good. This follows because light rather than $\mathrm{P}$ is limiting at this time (Sterner et al. 1997) and because diatoms and cryptophytes, which tend to have high PUFA concentrations, dominate. Winter and spring may be important to both dreissenids. The regions where the deep chlorophyll layer intersects the bottom ( 20-40 m) in Lake Michigan as well as in Lake Huron may be particularly favorable to quagga mussels.

Quagga mussels in the hypolimnion will be in contact with the total water column during isothermal seasons (late fall, winter, and spring in the Great Lakes), when the entire water column is mixed. At this time, they should exert negligible grazing pressure on the algal community because of the great depths of most Great Lakes having a hypolimnion. Greatest concentration of algae will be experienced during the spring bloom, when turbulence keeps the water column mixed and large diatoms such as Melosira in suspension (Scavia and Fahnenstiel 1987). During calm periods and at the onset of thermal stratification, there will be mass settling of large diatoms, a valuable food source for quagga mussels and other benthos. The burrowing amphipods Diporeia spp. that have historically dominated the biomass of transition $(30-50 \mathrm{~m})$ and profundal regions $(>50 \mathrm{~m})$ are thought to be especially dependent on this freshly settled material, because much of their lipid accumulation occurs during this period (Gardner et al. 1989). During stratification, smaller algae, particularly flagellates that occur in epilimnion and the hypolimnion, are less likely to sink and will be heavily grazed by zooplankton (e.g., Scavia and Fahnenstiel 1987), thus decreasing the rate of settling of high quality food to the deep benthos (Gardner et al. 1989). Therefore, competition for food in this food-limited environment (depths $>30 \mathrm{~m}$, Nalepa et al. 1998) between hypolimnetic dreissenids and dominant pre-dreissenid benthos (Diporeia, the depositfeeding oligochaete Stylodrilus, and sphaeriid clams, which dominated at depths $>30 \mathrm{~m}$ ) may be critical soon after thermal stratification. Also, as noted for zebra mussels, quagga mussels may find the deep chlorophyll layer of some Great Lakes an especially favorable environment.

\section{Echinogammarus ischnus}

The euryhaline benthic amphipod Echinogammarus ischnus is native and common in large, slowly moving rivers with stony substrates north of the Black Sea and is closely associated with Dreissena clumps in its native range (Dermott et al. 1998b). It is now spreading through Europe and the Great Lakes (Dermott et al. 1998b). A breeding population was first discovered in North America in the Detroit River in 1995 (Witt et al. 1997). Subsequent studies by Dermott et al. (1998b) in 1996 reported this species to be "widespread" from the south end of Lake Huron to the St. Clair River across Lake Erie to the Niagara River to Lake Ontario to the St. Lawrence River at Prescott. More recent sightings in 1999 indicate that the eastern range now extends to Quebec City in the St. Lawrence River (R. Dermott, Great Lakes Laboratory for Fisheries and Aquatic Science, Burlington, Ont., personal communication). Echinogammarus is now common in nearshore areas of the western two thirds of Lake Ontario (C. Mayer, Syracuse University, Syracuse, NY 13244, and R. Dermott, personal communications). Echinogammarus was first found in Lake Michigan in 1999 and is now found in abundance in nearshore rocky areas from the very north to south in Lake Michigan and in association with zebra mussels in deeper waters; a few individuals not associated with mussels where found to depths as great as $90 \mathrm{~m}$ (Nalepa et al. 2001). 
Echinogammarus rapidly displaced the native amphipod Gammarus fasciatus, the dominant littoral benthic invertebrate and important food for fishes, in rocky areas in the St. Clair and Detroit rivers and wave-exposed rocky areas in western Lake Erie and eastern Lake Michigan. Echinogammarus has replaced Gammarus on substrates with and without Dreissena in these areas (Dermott et al. 1998b; Bially and MacIsaac 2000; Nalepa et al. 2001). Like many amphipods, Echinogammarus is known to swim actively through the water, even against currents (reviewed in Nalepa et al. 2001). Dreissena spp. are producing habitat suitable for both species (Bially and MacIsaac 2000).

Great Lakes populations of Echinogammarus have a lower fecundity than Gammarus (Dermott et al. 1998b); replacement of Gammarus by Echinogammarus in wave-turbulent rocky areas is thought to be related to Echinogammarus' effective use of hard substrates (Dermott et al. 1998b). This same activity may make them more vulnerable to predation from round gobies. It is expected that the generalist G. fasciatus, which is well adapted to habitats with dense submerged vegetation or quiet turbid areas, will continue to dominate in such habitats (Dermott et al. 1998b), but that fish predation may determine relative dominance in rocky areas. Although much work remains to study production and competition of these two amphipod species and their linkage to fishes, the effects of replacement of $G$. fasciatus by E. ischnus on the ecosystem are likely to be subtle, because they fill similar roles in the food web (Dermott et al. 1998b).

\section{Round and tubenose gobies}

Round (Neogobius melanostomus) and tubenose (Proterorhinus marmoratus) gobies were discovered in 1990 in the St. Clair River (Jude 2001). The tubenose goby (maximum length $\approx 110 \mathrm{~mm}$, which prefers macrophyte beds and eats benthos) was geographically limited to Lake St. Clair, western Lake Erie, and some tributaries in these systems until 2001, when it was found in Duluth Harbor (western Lake Superior) (D. Pratt, Wisconsin Department of Natural Resources, Superior, WI 54880, personal communication), and it is too small to efficiently feed on zebra mussels (French and Jude 2001). Ecological impacts, therefore, are expected to be minimal. In contrast, the round goby, a larger (maximum length $\approx 250 \mathrm{~mm}$ ) and egg-guarding $r$ strategist, spread rapidly and now inhabits all five Great Lakes (Jude 2001); it was found as early as 1993 in the Grand Calumet River, a tributary of Lake Michigan, and in Duluth Harbor as early as 1996 (U.S. Geological Survey 2002). They are found in high abundance in the southern end of Lake Michigan, in the central basin of Lake Erie, the St. Clair River, Lake St. Clair, Duluth Harbor, and Bay of Quinte, Lake Ontario (Jude 2001). Round gobies are also common along the tributaries of the St. Clair River, Lake St. Clair, Lake Erie, and Lake Michigan. They flourish in rocky and debris-filled areas, where they can attain high $\left(19-40 \mathrm{fish} \cdot \mathrm{m}^{-2}\right)$ abundances, and recently have been invading offshore waters of Lakes Michigan and Huron up to $50 \mathrm{~m}$ (Jude 2001). Round gobies can feed at night because of their unique lateral line system and are larger than most co-inhabiting benthic species and females can spawn every 20 days up to six times during the year (Jude 2001).
Small round gobies $(<70 \mathrm{~mm})$ eat a variety of benthic macroinvertebrates (e.g., amphipods, isopods, insect larvae, benthic cladocerans) and zebra mussels, whereas zebra mussels dominate the diets of large round gobies (e.g., Ray and Corkum 1997; French and Jude 2001). Round gobies are gape-limited so that size of mussels ingested increases with goby length; however, in general, small mussels (<10 mm) are selectively cropped (Ray and Corkum 1997). Because few other fish eat zebra mussels (French 1993), round gobies that survive the early life-history stages have an ample food supply, which favors survival (Ray and Corkum 1997). As quagga mussels move into soft sediments of deep areas of the Great Lakes, they also will provide food for round gobies.

Round gobies represent another case of invasional meltdown (Ricciardi 2001). Zebra mussels facilitated the population establishment and expansion of the round goby by providing a major food source for large fish and habitat for small invertebrates such as amphipods, which are prey of small round gobies (Fig. 3; French and Jude 2001). Round gobies are altering benthic communities associated with dreissenids by removal of non-dreissenid invertebrates, which in turn affect benthic plants they prey upon, and by removal of the mussels themselves (Kuhns and Berg 1999), which provide habitat and food for benthic invertebrates and light and nutrients for benthic plants (Fig. 3).

Laboratory studies have shown that round gobies are aggressive and displace mottled sculpins (Cottus bairdi) from shelters (Dubs and Corkum 1996). Round gobies in the St. Clair River and southern Lake Michigan have decimated mottled sculpin populations by competing with them for food at small sizes, for space at intermediate sizes, and for spawning substrate (both species spawn on the undersides of rocks, logs, etc.) at larger sizes (Janssen and Jude 2001; Jude 2001). Populations of round gobies in Lake Erie have not affected mottled sculpin abundance at trawlable (soft sediments) offshore sites; however, nothing is known about interactions on reefs, which are not accessible to trawling (Jude 2001). That round gobies are found in deep water during winter may have negative consequences to slimy sculpins (Cottus cognatus) and deepwater sculpins (Myoxocephalus thomsoni), which inhabit this region (Jude 2001). The replacement of the deepwater benthic amphipod Diporeia by Dreissena in this region (see below) may put the sculpins, which heavily prey on Diporeia, at a further disadvantage relative to round gobies.

The egg eating and habitat preference for hard substrates of round gobies may lead to serious consequences for spawning of some native fish species. Laboratory experiments have established round gobies as lake trout egg predators (Chotkowski and Marsden 1999), and they will likely eat fry as well (French and Jude 2001). The combination of goby predation and colonization of interstitial spaces by zebra mussels will most likely render nearshore reefs less optimal habitat for spawning lake trout. This scenario is probably taking place on the newly laid breakwater at the Port of Indiana (Burns Harbor) in southern Lake Michigan, which has attracted large numbers of lake trout, but which also contains high abundances of round gobies (e.g., Chotkowski and Marsden 1999; Jude 2001). There is also concern that round gobies, which prey heavily on lake sturgeon eggs, will harm this endangered species (Jude 2001). 
Fig. 4. Contrast between morphology and size of Cercopagis pengoi (upper) and Bythotrephes cederstroemi (lower) collected in Lake Michigan in July-August 2000 in 45-m-deep waters off Muskegon, Michigan. Arrows point to the first thoracopods, which putatively would be important for grasping and holding large prey.

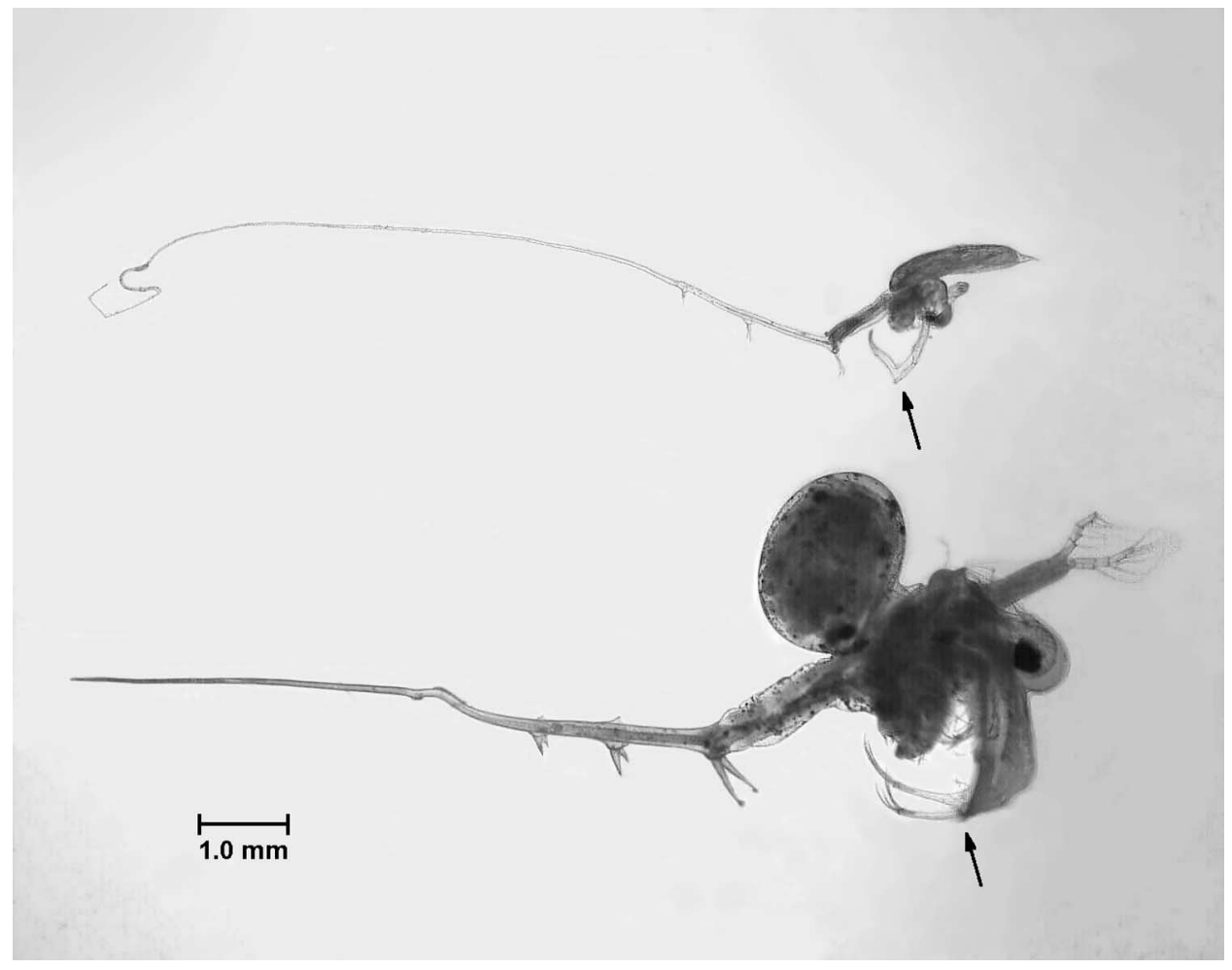

Round gobies may also change toxic substance transfer routes; some high accumulations of polychlorinated biphenyls (PCBs) have been recorded in round gobies in the PCBcontaminated Raisin River, a tributary to Lake Erie (Jude 2001). Presumably they acquired high concentrations from eating contaminated zebra mussels, and this pathway could lead to contamination of game fishes that prey on gobies (e.g., Jude 2001).

\section{Cercopagis pengoi, Bythotrephes, and the pelagic ecosystem of the Great Lakes}

Cercopagis pengoi was first observed in the Great Lakes in 1998 in Lake Ontario, where it became an important component of the crustacean zooplankton by September 1999 (Makarewicz et al. 2001). By the summer of 1999, it had spread to five of the seven nearby $(\sim 50 \mathrm{~km})$ Finger Lakes of New York State and to Lake Michigan (Charlebois et al. 2001; Makarewicz et al. 2001). In Lake Michigan, populations increased during 2000 and 2001, and high concentrations $\left(>1000 \mathrm{~m}^{-3}\right)$ were occasionally found in nearshore areas (H. Vanderploeg, unpublished data). Cercopagis was found in Lake Erie and the Detroit River during the summer 2001 (T. Therriault and I. Grigorovich, University of Windsor, Windsor, Ont., personal communication). Considering the similarity of the ecology of Lakes Michigan and Huron, Cercopagis would be expected to become an important component of the Lake Huron plankton. We do not expect it to become a major component of the plankton offshore of the cold, oligotrophic Lake Superior, which is not a good habitat because of its short period of stratification and low concentra- tions of cladoceran prey favored by Cercopagis (see below). This invasion pattern seems to parallel that seen for another cercopagid, the Palearctic Bythotrephes cederstroemi, that spread rapidly among the Great Lakes during the 1980s (Lehman and Cáceres 1993).

Cercopagis shares many traits with Bythotrephes (Fig. 4). Like $B$. cederstroemi, $C$. pengoi is an epilimnetic (Rivier 1998; Makarewicz et al. 2001) predator of zooplankton that has similar swimming and feeding appendages (e.g., Rivier 1998) and a long tail spine that restricts its use as a food source to fishes (e.g., Ojaveer et al. 2000). Both are $r$ strategists that reproduce by parthenogenesis with short generation times for rapid population growth during summer and the production of resting eggs that survive over winter (Rivier 1998). These similarities imply that Cercopagis will have some impacts in common with Bythotrephes and that there may be competitive and predatory interactions between these two species. Their potential roles in the Great Lakes food web (Fig. 5) imply that these two cercopagids compete with small fish for zooplankton,

Other food-web concerns include increased biomagnification of contaminants associated with lengthening the food chain and cascading trophic effects. Cabana et al. (1994) showed that an increase in both $\mathrm{Hg}$ and PCBs in fishes as food-web length was increased. It was argued that Bythotrephes (Lehman and Cáceres 1993) and Cercopagis (Makarewicz et al. 2001) predation on crustacean zooplankton would cascade down the food web to increase phytoplankton concentration; however, this scenario ignores the potentially important role played by protozoans and rotifers in controlling phytoplankton populations (Fig. 5). 
Fig. 5. Bythotrephes cederstroemi and Cercopagis pengoi in the epilimnetic food webs of the Great Lakes and their connection to important epilimnetic forage fishes, which would be alewives in Lakes Michigan, Huron, and Ontario, lake herring in Lake Superior, and rainbow smelt and a variety of shallow-water planktivores in Lake Erie. Thick arrows indicate high selectivities (preferences; e.g., Vanderploeg et al. 1993) of the consumer, and thin arrows indicate low selectivities. We anticipate that Cercopagis would prefer smaller cladocerans (Bosmina) than would Bythotrephes and that Cercopagis could be prey of Bythotrephes. The dotted line with two arrowheads on it implies potential competitive interactions because of similar diet preferences.

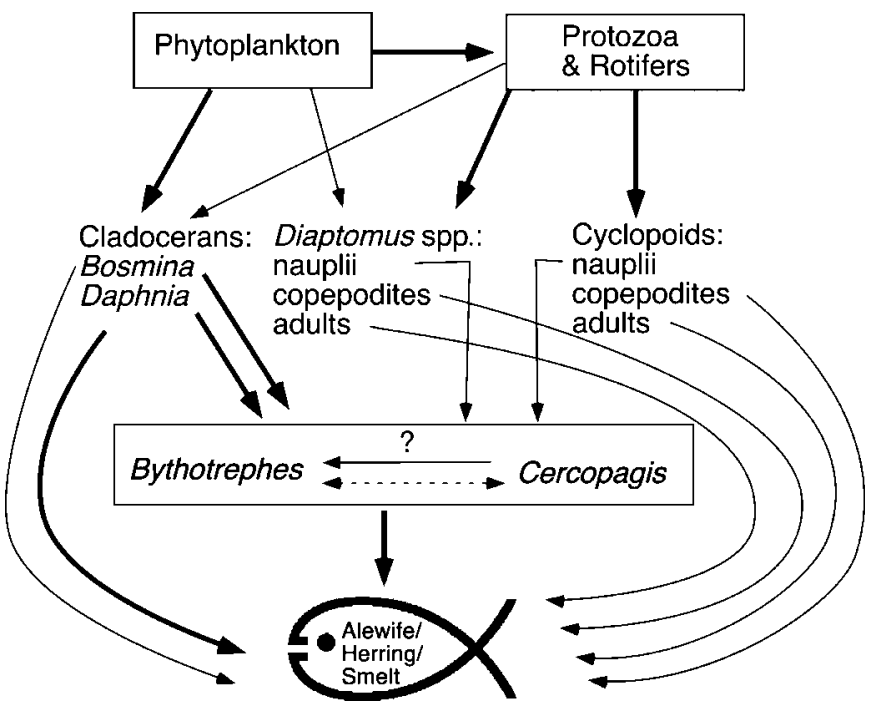

Although the body of $C$. pengoi is much smaller than that of Bythotrephes, its spine is nearly the same length (Fig. 4). The spine protects Bythotrephes from predation by fishes smaller than 3-5 cm (Branstrator and Lehman 1996) and C. pengoi from fishes smaller than 3-4 cm (Ojaveer et al. 2000). Both cercopagids are favored prey of large, visually feeding planktivorous fishes. Bythotrephes, which is larger and tends to be more highly pigmented than Cercopagis (H. Vanderploeg, unpublished data), would be preyed upon more heavily than Cercopagis.

Bythotrephes has a high maximum ingestion rate (100$150 \%$ body C.day ${ }^{-1}$; Yurista and Schulz 1995) and efficiently feeds on a broad size range of cladocerans, including large Daphnia (Vanderploeg et al. 1993; Schulz and Yurista 1999), because its large feeding appendages (Fig. 4) can capture and manipulate large prey for piercing them and sucking out their soft parts (Rivier 1998; Schulz and Yurista 1999). Selectivities (food preferences) for copepod copepodite stages and adults (Fig. 5) are very low because of their superior escape abilities (Vanderploeg et al. 1993; Schulz and Yurista 1999). However, copepod nauplii can be more easily captured than copepodites or adults and can be an important food source if cladocerans are not available (Vanderploeg et al. 1993). The smaller size of Cercopagis would imply that it could not eat prey as large as those consumed by Bythotrephes since its 1st thoracopods are much shorter than those of Bythotrephes (Fig. 4). In the Gulf of Riga (Baltic Sea), long-term population studies indicate that populations of the small cladoceran Bosmina declined following invasion by $C$. pengoi (Ojaveer et al. 2000). It is con- sistent with the assumed preference of Cercopagis for small zooplankton that its populations exploded in Lake Ontario, a lake dominated by small zooplankton. In Lake Ontario, high abundances of Cercopagis were associated with lowered abundance of juvenile copepods (Benoît et al. 2002). In addition, the juvenile copepods were found deeper in the water column, possibly a response to escape Cercopagis in the epilimnion.

The small size of Cercopagis relative to Bythotrephes suggests Cercopagis could be prey of Bythotrephes if they cooccur in surface waters, because Bythotrephes is known to cannibalize its young (Rivier 1998; Schulz and Yurista 1999). Note that the thoracopods of Bythotrephes are not only longer but are more massive than those of Cercopagis, suggesting that if captured, Cercopagis would be overpowered. Except in nearshore areas, we have observed only low densities of Cercopagis to date in Lake Michigan, where Bythotrephes densities have remained high ( $\mathrm{H}$. Vanderploeg, unpublished data). In contrast in Lake Ontario, where Bythotrephes populations are extremely low, probably a result of strong predation pressure from alewives (Mills et al. 1992), Cercopagis populations have exploded. These results offer some circumstantial evidence for possible predation of Bythotrephes on Cercopagis or possibly competitive interactions.

\section{Predicted impacts of the cercopagids-a minus or plus to fishes in the pelagic food web?}

Food-web impacts of Bythotrephes in Lake Michigan suggest that there may be impacts from Cercopagis as well. Following the establishment of Bythotrephes, there was a precipitous decline of all three species of Daphnia (pulicaria, retrocurva, and galeata mendotae) in Lake Michigan. Daphnia galeata mendotae recovered and became the dominant species in subsequent years, possibly because it avoided predation from Bythotrephes by vertical migration to limit overlap (Lehman and Cáceres 1993). Calculations of predation demand indicated that Bythotrephes was capable of removing a large fraction of all of cladoceran production in Lake Michigan.

Impacts from Cercopagis are likely if the high densities of Cercopagis seen initially in Lake Ontario continue and if they compete with larval and young-of-year fishes, which are planktivores, and with planktivorous fishes, in general. There has been concern about the poor recruitment since 1989 of yellow perch in nearshore Lake Michigan that has been attributed to poor survival during the first few months of life (Francis et al. 1996). Competition of Bythotrephes with perch for zooplankton was hypothesized to be one of the causes of this decline. The same concern would apply to Cercopagis, which would prey on smaller cladocerans (Fig. 5). Also, these impacts may combine with those of Bythotrephes.

The question as to whether Cercopagis can be a benefit to fishes in the pelagic food web and not just an energy drain by adding another link to the food chain depends on whether it serves the useful function of packaging up small zooplankton too small to be efficiently captured by planktivorous fishes into larger Cercopagis body mass that is more efficiently preyed upon (Ojaveer et al. 2000). Because of the relatively large size of cercopagid prey, the benefit from repackaging may be small. In addition, lengthening the food 
web will probably increase contaminant concentrations in fishes.

\section{Impacts of benthic Ponto-Caspian invaders-case studies}

In this section, we examine or construct (from many separate studies) case histories for Great Lakes sites where ecological impacts on water quality and important components of the food web are well documented, particularly with respect to dreissenid biomass. These sites include Saginaw Bay (Lake Huron), western Lake Erie, Long Point Bay (Lake Erie), Lake St. Clair, and deepwater basins of eastern Lake Erie, Lake Michigan, and Lake Ontario. These case studies will also serve to detail connections between Ponto-Caspian invaders and upper food web predators such as fishes and waterfowl (Fig. 3).

\section{Bays and shallow basins}

\section{Comparison of Saginaw Bay and western Lake Erie}

Saginaw Bay is a well-mixed extension of Lake Huron. Most of the studies of the bay have been within the $1550 \mathrm{~km}^{2}$ shallow (mean depth $=5.1 \mathrm{~m}$ ) inner bay, where the combination of high zebra mussel concentration and shallow water depth has led to the greatest dreissenid impact. Water residence time is 120 days. During the 1960 s and 1970s, Saginaw Bay was quite eutrophic; however, with decreases in $\mathrm{P}$ loading and resulting improvements to water quality, the bay was much less eutrophic at the time that zebra mussels became established in 1991. During 1974-1980, spring TP concentrations ranged from $26 \mu \mathrm{g} \cdot \mathrm{L}^{-1}$ to $47 \mu \mathrm{g} \cdot \mathrm{L}^{-1}$ and during 1991-1996 between $7 \mu \mathrm{g} \cdot \mathrm{L}^{-1}$ and $25 \mu \mathrm{g} \cdot \mathrm{L}^{-1}$. During spring through fall 1991-1996, soluble reactive phosphorus (SRP) concentration was usually $<1 \mu \mathrm{g} \cdot \mathrm{L}^{-1}$ (Nalepa et al. 1996a; Johengen et al. 2000).

Western Lake Erie is a shallow basin (mean depth $=7.4 \mathrm{~m}$ ) with a residence time of 51 days. It has seen a large decline (>50\%) in P loading from 1970 to the early 1980s that has transformed the formerly eutrophic basin to a mesotrophic basin (Dahl et al. 1995); however, SRP values are higher than those in Saginaw Bay (see below).

Zebra mussels colonized the cobble, gravel, and sandy surfaces that covered about $70 \%$ of inner Saginaw Bay and quickly reached a maximum density in 1992 (Fig. 6a). The zebra mussel population crashed in 1993 only to rebound in 1996. In western Lake Erie, zebra mussels quickly colonized hard substrates, increasing from 400 to maximum levels of 341000 individuals $\cdot \mathrm{m}^{-2}$ within $1-2$ years of their invasion (MacIsaac et al. 1991). In Saginaw Bay, FC was extremely high in 1992 (Fig. 6a) because mussel biomass was so high. Although the FC during 1993 to 1996 was relatively modest (0.2-0.8 day $\left.^{-1}\right)$, FC was operating against a P-limited algal community growth rate of only $0.20-0.25$ day $^{-1}$ (Fahnenstiel et al. 1995).

Zebra mussels dominated metazoan grazing in Saginaw Bay. Crustacean zooplankton biomass was typically $<0.25 \mathrm{~g}$ $\mathrm{DW} \cdot \mathrm{m}^{-2}$ and FC was typically $<0.03$ day $^{-1}$ (Bridgeman et al. 1995; H. Vanderploeg, unpublished data). Chlorophyll $a$ concentrations in spring 1990 and 1991, before zebra mussels became abundant, were higher than in succeeding years, and water clarity measured in spring 1991 was much lower
Fig. 6. Impacts of zebra mussels on inner Saginaw Bay (mean depth $=5.1 \mathrm{~m})$ : $(a)$ biomass of zebra mussels measured each fall in inner Saginaw Bay (Nalepa et al. 1999; T. Nalepa, unpublished data) and the fraction of the 5.1-m-deep water column cleared per unit time using a filtering rate of $11.7 \mathrm{~L} \cdot \mathrm{g}$ dry weight $^{-1} \cdot \mathrm{h}^{-1}$ (Kryger and Riisgård 1988); (b) seasonal chlorophyll $a$ concentration, and (c) Secchi disc readings averaged from eight master stations (Nalepa et al. 1996a; Johengen et al. 2000).
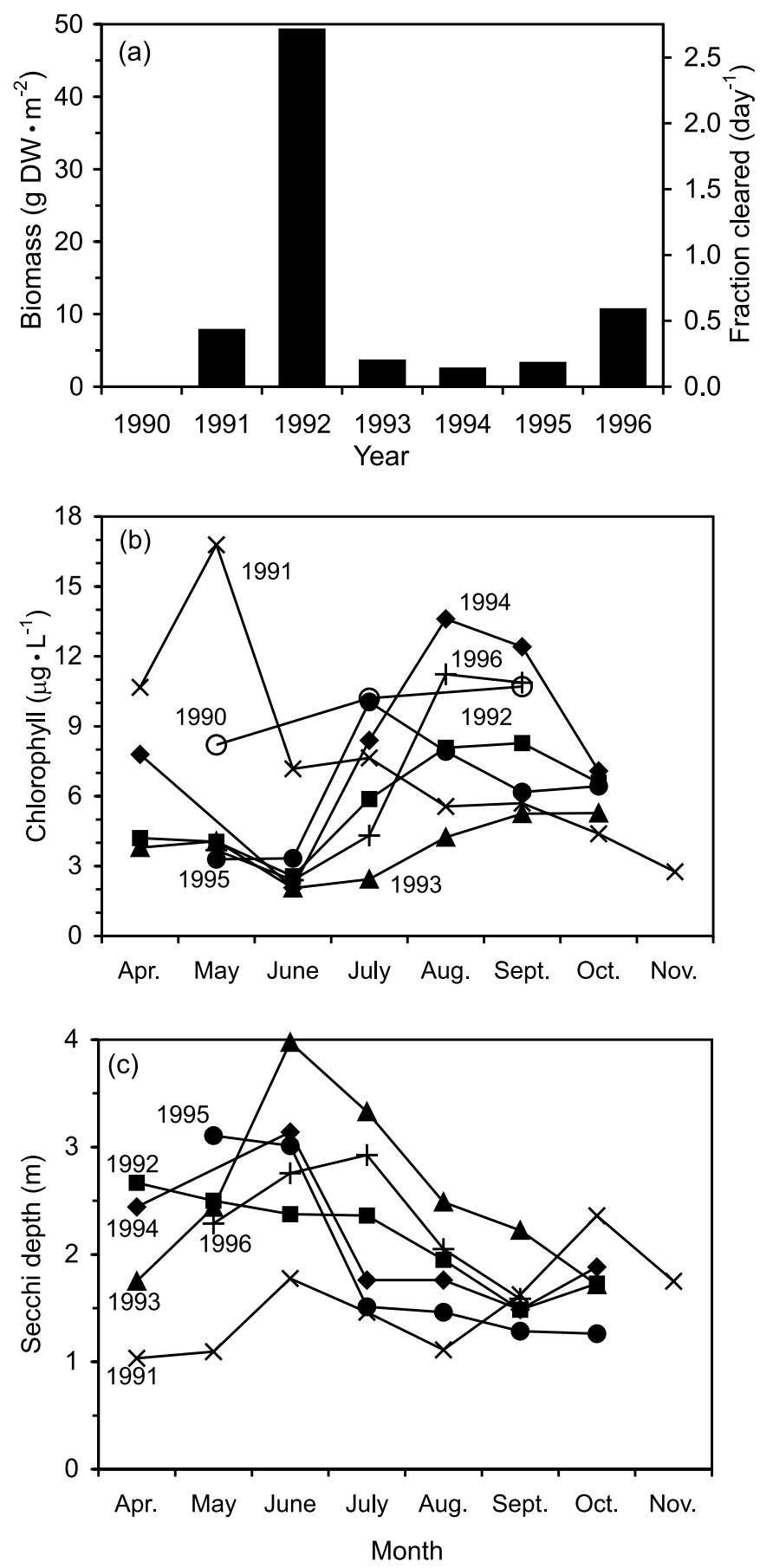

than in subsequent years (Fig. 6c). However, the clear water phase of spring gave way to higher chlorophyll $a$ concentrations during summer and early fall (Fig. 6b). In 1992, 1994, and 1995, these chlorophyll peaks were associated with Microcystis aeruginosa dominance, possibly promoted by selec- 
tive rejection of Microcystis in pseudofeces (Vanderploeg et al. 2001). In contrast to western Lake Erie, where SRP concentrations increased after the zebra mussel invasion (Makarewicz et al. 2000), SRP concentrations decreased in Saginaw Bay (Johengen et al. 1995, 2000). In 1995-1997, when seston $\mathrm{C}: \mathrm{P}$ and $\mathrm{N}: \mathrm{P}$ were measured, $\mathrm{C}: \mathrm{P}$ and $\mathrm{N}: \mathrm{P}$ mass ratios $(\mathrm{C}: \mathrm{P}=142$ and $\mathrm{N}: \mathrm{P}=18)$ in spring to fall 1995-1997 in Saginaw Bay (T. Johengen and H. Vanderploeg, unpublished data) were considerably higher than the Redfield ratios $(\mathrm{C}: \mathrm{P}=41$ and $\mathrm{N}: \mathrm{P}=7.2)$ and were above values suggesting severe $\mathrm{P}$ limitation $(\mathrm{C}: \mathrm{P}=100$ and $\mathrm{N}: \mathrm{P}=9.9$; Hecky et al. 1993). Corresponding values for Hatchery Bay, Lake Erie, were SRP $=4.6 \mu \mathrm{g} \cdot \mathrm{L}^{-1}, \mathrm{C}: \mathrm{P}=44$, and $\mathrm{N}: \mathrm{P}=5.9$ (T. Johengen and H.Vanderploeg, unpublished data). Thus, the contrasting changes in SRP in these two systems are consistent with the zebra mussel skewing $\mathrm{N}: \mathrm{P}$ ratios via homeostatic nutrient excretion.

Unfortunately we do not have good time histories of dreissenid biomass in western Lake Erie, which makes it difficult to quantify time history of filtering impact. Early, often-quoted high estimates of FC (14-26 day ${ }^{-1}$ ) for conditions in 1990 relied on applying the Kryger and Riisgård (1988) equations to numbers and lengths of mussels found on hard substrate reefs (e.g., MacIsaac et al. 1991, 1992), which make up $\sim 15 \%$ of the substrate in western Lake Erie. Assuming that mussels were restricted to $15 \%$ of the area of western Lake Erie, MacIsaac et al. (1992) estimated that FC was $2.0 \mathrm{day}^{-1}$. Using a biomass that accounted for substrate and depth varying dreissenid biomass in 1992 and 1993 as an "equilibrium" estimate of mussel biomass (Table 1), we calculated FC $=1.0$ day $^{-1}$. It is possible that densities were initially higher on easily colonized hard substrates in 1990 and then populations declined, as they did in Saginaw Bay by 1993 .

Dramatic changes were evident in chemistry, phytoplankton, and chlorophyll $a$ at offshore western Lake Erie sites between pre- (1983-1988) and post-Dreissena (19891993) years for spring and late summer (Makarewicz et al. 2000). Spring SRP values increased from $1.0 \mu \mathrm{g} \cdot \mathrm{L}^{-1}$ to $2.8 \mu \mathrm{g} \cdot \mathrm{L}^{-1}$, and summer values increased from $1.2 \mu \mathrm{g} \cdot \mathrm{L}^{-1}$ to $1.7 \mu \mathrm{g} \cdot \mathrm{L}^{-1}$. Perhaps the mussels improved conditions for algal growth by excreting $\mathrm{PO}_{4}$. No measurements were made for seston C:P or N:P. In parallel with results for Saginaw Bay, average chlorophyll $a$ concentration in offshore western Lake Erie was lower $\left(3.1 \mu \mathrm{g} \cdot \mathrm{L}^{-1}\right)$ in spring after the invasion of zebra mussels than before $\left(7.5 \mu \mathrm{g} \cdot \mathrm{L}^{-1}\right)$; summer chlorophyll concentrations after the invasion $\left(9.2 \mu \mathrm{g} \cdot \mathrm{L}^{-1}\right)$, however, were not significantly lower than those before $\left(10.2 \mu \mathrm{g} \cdot \mathrm{L}^{-1}\right)$ (Makarewicz et al. 2000). Also, Dahl et al. (1995) estimated that seasonal photosynthesis in the western basin was $23 \%$ lower than that predicted from photosynthesis vs. TP relationship. Interestingly, turbidity significantly increased after the zebra mussel invasion for spring but was unchanged during summer (Makarewicz et al. 2000). Presumably non-algal material such as resuspended sediments from areas having silty or muddy substrate, as described above for the Hudson River, was responsible for the increase in turbidity.

In Saginaw Bay, spring turbidities decreased, as seen by the increase in depth of Secchi disc visibility (Fig. 6c). Sediment resuspension as a source of turbidity was less probable in Saginaw Bay than in western Lake Erie because of the predominance of larger-grained sediments in Saginaw Bay. Chlorophyll $a$ concentrations in Saginaw Bay summarized from Nalepa et al. (1999) for spring and late summer - fall periods after (1992-1995) zebra mussel colonization were $3.7 \pm 0.4$ (4) $\mu \mathrm{g} \cdot \mathrm{L}^{-1}$ and $7.6 \pm 1.3$ (4) $\mu \mathrm{g} \cdot \mathrm{L}^{-1}$, respectively. These results are remarkably similar to those for Lake Erie, where SRP concentration is considerably higher.

As might be expected from the increased water clarity of Saginaw Bay during spring (Fig. 6c), the vascular hydrophyte Chara and various benthic filamentous green algae increased, some of them attached to the zebra mussels themselves (Lowe and Pillsbury 1995; Skubinna et al. 1995). Based on amount of light reaching the benthic algal community, it was hypothesized that any loss of primary production in the pelagic realm was compensated for by primary production by benthic plants (Fahnenstiel et al. 1995). Unfortunately, there are no estimates of benthic plant biomass available for the inner bay. The mussels also improved conditions for the macrophytes by nutrient excretion, particularly those attached to or near the mussels. Possibly, the macrophytes, like the mussels, sequestered some of the $\mathrm{P}$ and are partly responsible for SRP decreasing. The somewhat greater mean depth $(7.4 \mathrm{~m})$ of western Lake Erie may have prevented benthic plants from being dominant primary producers and sinks for P. In Saginaw Bay, green filamentous algae such as Spirogyra (too large to be eaten by zooplankton and attached on hard substrates or free floating in the water column) would drift onshore and become a nuisance (Lowe and Pillsbury 1995).

In Hatchery Bay (western Lake Erie), zooplankton density decreased in the years following the zebra mussel invasion (1990-1993) relative to years before (1984-1985) the invasion, with most of the loss in numbers being due to rotifers and copepod nauplii (Beeton and Hageman 2000). At offshore and inshore sites near the north shore of Lake Erie, Dahl et al. (1995) observed that crustacean biomass in 1993 was only slightly lower when compared with 1984-1987, whereas rotifer biomass declined greatly. Estimates of total zooplankton production in the middle of the western basin were $85 \%$ of what would be expected for the given level of TP and planktivory (Johannsson et al. 2000). Generally, grazing impacts of crustacean zooplankton and rotifers would be expected to be small relative to that of the mussels because their average seasonal biomass was small compared to mussel biomass (Table 1).

Although zebra mussels accounted for $95 \%$ of the shellfree wet biomass of benthic invertebrates in the western basin of Lake Erie in 1993, benthic invertebrates, except for the extirpated unionid mussels, had approximately the same abundances as they did in 1979 (Johannsson et al. 2000). However, in 1993 relative to 1979, there was a dramatic increase in Gammarus, which was associated with zebra mussel clusters (Dahl et al. 1995). Johannsson et al. (2000) calculated for two monitoring stations in the western basin for 1993 that the contribution of dreissenids, other benthos, and zooplankton to annual production was $78-93 \%, 1-5 \%$, and $6-17 \%$, respectively. The observed changes in zooplankton and benthos suggest that extremely high dreissenid biomass and production apparently came at no cost to the benthos and modest cost to crustacean zooplankton. In addition, there was a widespread population recovery starting in 
1993-1995 of the deep burrowing, detritus-feeding mayfly, Hexagenia: population projections suggested a return to historic high population levels by 2000 (Edsall et al. 1999). Hexagenia nymphs are extremely important in the diet of fishes such as yellow perch because of their large size (Edsall et al. 1999). Improving water-quality trends including increased dissolved oxygen concentration, whether or not related to dreissenids, are thought to be responsible for the resurgence of this species in western Lake Erie (Edsall et al. 1999). It is an interesting question whether the mussels' removal of particulate material from the water column and its transformation into feces and pseudofeces increases food available for Hexagenia burrowing in soft sediments. Or is Hexagenia mining a previously laid down energy source that will not be renewed but be depleted by continuing filtering activities of dreissenids?

Marine mussels have been portrayed as ecosystem stabilizers and a natural eutrophication control that regulate phytoplankton concentration under varying nutrient loads (e.g., Herman and Scholten 1990). A corollary to this paradigm is that in freshwater, water clarity will increase in the presence of dreissenids. The similar chlorophyll $a$ concentrations in Saginaw Bay and western Lake Erie, which have different P loading and SRP concentrations, are consistent with this paradigm. However, mussels were not able to control (decrease) summer concentrations of chlorophyll $a$ in Saginaw Bay or in Lake Erie or maintain spring levels of water clarity into summer (Fig. 6). Moreover, the lack of control or promotion of Microcystis blooms in Saginaw Bay and Lake Erie by dreissenids is particularly inconsistent with this paradigm: Microcystis bloomed three out of five summers after invasion by zebra mussels, and there were very intense blooms on western Lake Erie in September 1995 (Vanderploeg et al. 2001) and August 1998 (T. Granata, Ohio State University, Columbus, Ohio, personal communication). Perhaps an explanation for this contradiction is that in marine estuarine systems, many of which have considerable flow, the mussels may be downstream of forces that determine algal composition and abundance, whereas the feedback of selective algal rejection operates in lake systems with low water turnover rates to influence algal composition. The algal composition in turn would have an effect on mussel growth and survival. Mussels from Saginaw Bay, where food quality is low because of a lack of favored algae (cryptophytes and flagellates), are much lighter per unit length than those from Lake Erie (H. Vanderploeg, unpublished data).

Another surprising result was that the dominance of pelagic and benthic production by dreissenids had only minimal effects on other benthos, except for the extirpated unionids, and little effect on zooplankton and no detectable effect on age-0 fishes (Trometer and Busch 1999) that depend on zooplankton. It is not clear whether this is a transitional state and that mussel filtering ultimately adversely affects zooplankton, Hexagenia, and other benthos through food competition.

\section{Long Point Bay, Lake Erie-an important waterfowl habitat}

Long Point Bay on Lake Erie, particularly the protected eutrophic $78 \mathrm{~km}^{2}$ inner bay, is a major staging area for waterfowl: over 100000 ducks, geese, and swans use the bay and associated wetlands during spring and fall migrations (Petrie and Knapton 1999). Improving water quality and the zebra mussel invasion in 1990 have had profound consequences to waterfowl populations, particularly greater scaup and lesser scaup (Aythya affinis, A. marila) and buffleheads (Bucephala albeola) (Knapton and Petrie 1999; Petrie and Knapton 1999). These three species are diving ducks that preyed heavily on zebra mussels in the shallow (2 m mean depth) inner bay (Petrie and Knapton 1999). The zebra mussels used macrophytes, which cover $90 \%$ of the bottom of this muddy and silty bay, as substrate (Petrie and Knapton 1999). The ducks preferred feeding on large (>7 mm) mussels (Hamilton and Ankney 1994). Migratory patterns of these species changed to take advantage of the mussels in the bay: scaup use of the bay increased from 0.04 million days before the zebra mussel invasion to 3.5 million days by 1997 , despite declining continental populations. Zebra mussels peaked in 1992, and it is quite possible that heavy consumption of mussels (43-230\% of mussel biomass) by the abundant scaups (Petrie and Knapton 1999) was responsible for the later decline in mussel abundance. During this same period desirable clear-water waterfowl plant foods such as Vallisneria and Chara increased, whereas the exotic Myriophyllum spicatum, which is of low nutritional value and does well in turbid conditions, decreased. Light conditions in the bay improved from the 1960s to 1990: Secchi disc readings increased from $1.7 \mathrm{~m}$ to $2.0 \mathrm{~m}$. Knapton and Petrie (1999) hypothesized that the mussels were responsible for the change. However, at peak mussel density, Petrie and Knapton (1999) estimated that the relatively low concentration of mussels in inner Long Point Bay would clear the water every 17 days. This seems like a small contribution to improving water clarity considering typical algal growth rates. Perhaps other factors such as lowered P loading to the bay (Petrie and Knapton 1999) and exchange of water from the open coast, where mussels are more abundant (Johannsson et al. 2000), may have been important factors. In any event, macrophytes provided substrate for zebra mussels that became an important food source for diving ducks during their migration, and zebra mussel populations were controlled to some considerable degree by duck predation (Fig. 3). Although feeding conditions improved for planteating ducks (dabbling ducks) in the bay, almost all of the increase in duck use of the bay came from mussel-eating diving ducks (Knapton and Petrie 1999; Petrie and Knapton 1999).

Although feeding conditions of the mussel-eating diving ducks has improved, there is concern that relative to other waterfowl foods, zebra mussels have high concentrations of contaminants (Petrie and Knapton 1999), which could possibly decrease the reproductive output of the ducks (Petrie and Knapton 1999). Because a substantial fraction of continental populations of scaup use Long Point Bay, there could be effects on the continental populations as a whole (Petrie and Knapton 1999).

\section{Lake St. Clair}

Lake St. Clair is a $1100-\mathrm{km}^{2}$ water body connecting Lake Huron and Lake Erie; water turnover in the lake is high (9 days) in this oligotrophic-mesotrophic system (Nalepa et al. 1996b). This ecosystem has a good time series of zebra mussel abundance (Nalepa et al. 1996b) and intensive environmental and fisheries studies (D. MacLennan, Ontario 
Ministry of Natural Resources Lake Erie Management Unit, Wheatley, Ont., and R. Haas and M. Thomas, Michigan Department of Natural Resources Lake St. Clair Great Lakes Station, Mt. Clemens, MI 48045, unpublished data), which allow examination of impacts of Ponto-Caspian invaders on the fisheries of Lake St. Clair. The southeastern two-thirds of the lake, or Canadian portion of the lake, is of more interest because it is out of the direct flow of the incoming St. Clair River, has a longer retention time, and is a more sheltered lake environment with soft sediments.

Zebra mussel colonization of Lake St. Clair has led to the local extirpation of 18 species of native unionids (Nalepa et al. 1996b). The change in community composition and filtering impact of the mussels (Fig. 7) has had large effects. The high fractions of the water column cleared $\left(0.29-0.45\right.$ day $\left.^{-1}\right)$ by Dreissena (Fig. 7) had the potential to remove a substantial portion of algal growth and suspended particulate material and increase light available to benthic plants (Figs. 2 and 3 ). The filtering impact for the Canadian portion of the lake was actually much higher because biomass was higher in this region. Filtering by dreissenids has increased water clarity and changed the previously turbid pelagic system into a clear-water, macrophyte-dominated system (D. MacLennan, R. Haas, and M. Thomas (addresses as above), unpublished data). Subsequently, Secchi disc measurements increased by a factor of two (from $1.4 \mathrm{~m}$ to $2.8 \mathrm{~m}$ ), and light penetrated to the bottom of many areas of this shallow ( $3 \mathrm{~m}$ deep) lake. July-August chlorophyll $a$ values decreased by $63 \%$ between the 1970s and 1991-1993. Lowest chlorophyll $a$ concentrations were seen in areas with the most mussels. However, chlorophyll concentrations rebounded to 1970 s levels in 1994-1996.

Changes in water clarity and macrophyte abundance in Lake St. Clair had important consequences to sport fishes (D. MacLennan, R. Haas, and M. Thomas (addresses as above), unpublished data) through various mechanisms (Fig. 3). Macrophyte biomass, particularly Chara and Vallisneria, increased five-fold in areas surveyed in eastern Lake St. Clair between 1985-1986 and 1994. Increased macrophyte abundance, particularly Chara, increased spawning and feeding habitat for a number of sport fishes, including muskellunge (Esox masquinongy), smallmouth bass (Micropterus dolimieu), and yellow perch, and decreased low-light habitat preferred by walleyes (Stizostedion vitreum). Chara is particularly important as a substrate for muskellunge spawning. Subsequently, abundance of smallmouth bass and muskellunge tripled, and walleye decreased by $50-75 \%$.

Feeding conditions for some piscivores improved as round gobies became abundant (Fig. 3) and an important component of the diet of muskellunge, smallmouth bass, yellow perch, and other piscivores (D. MacLennan, R. Haas, and M. Thomas, unpublished data). However, round gobies never became an important diet component of the declining walleyes. Smaller round gobies profited from the putative increase in invertebrates, whereas larger gobies benefitted from and abundant zebra mussel population (Jude 2001). Also, feeding conditions for a variety of planktivores and benthivores may have improved owing to increased light intensity (Fig. 3; Mayer et al. 2000). In eutrophic Oneida Lake, where crustacean biomass did not change, increased water clarity resulting from zebra mussel filtration was asso-
Fig. 7. Shift in mussel community structure from unionids to Dreissena $(a)$, in units of flesh dry mass (DW), in Lake St. Clair (mean depth $=3.06 \mathrm{~m}$ ) (Nalepa et al. 1996b) and its consequences to filtering impact expressed as fraction of the water column cleared per unit time $(b)$. Filtering rates were assumed to be $11.7 \mathrm{~L} \cdot \mathrm{g} \mathrm{DW}^{-1} \cdot \mathrm{h}^{-1}$ for Dreissena (Kryger and Riisgård 1988) and $0.818 \mathrm{~L} \cdot \mathrm{g} \mathrm{DW}^{-1} \cdot \mathrm{h}^{-1}$ for unionids using the average seasonal filtering rate in Lake St. Clair (Vanderploeg et al. 1995).

Dreissenids $=$ hatched bars, unionids = solid bars.
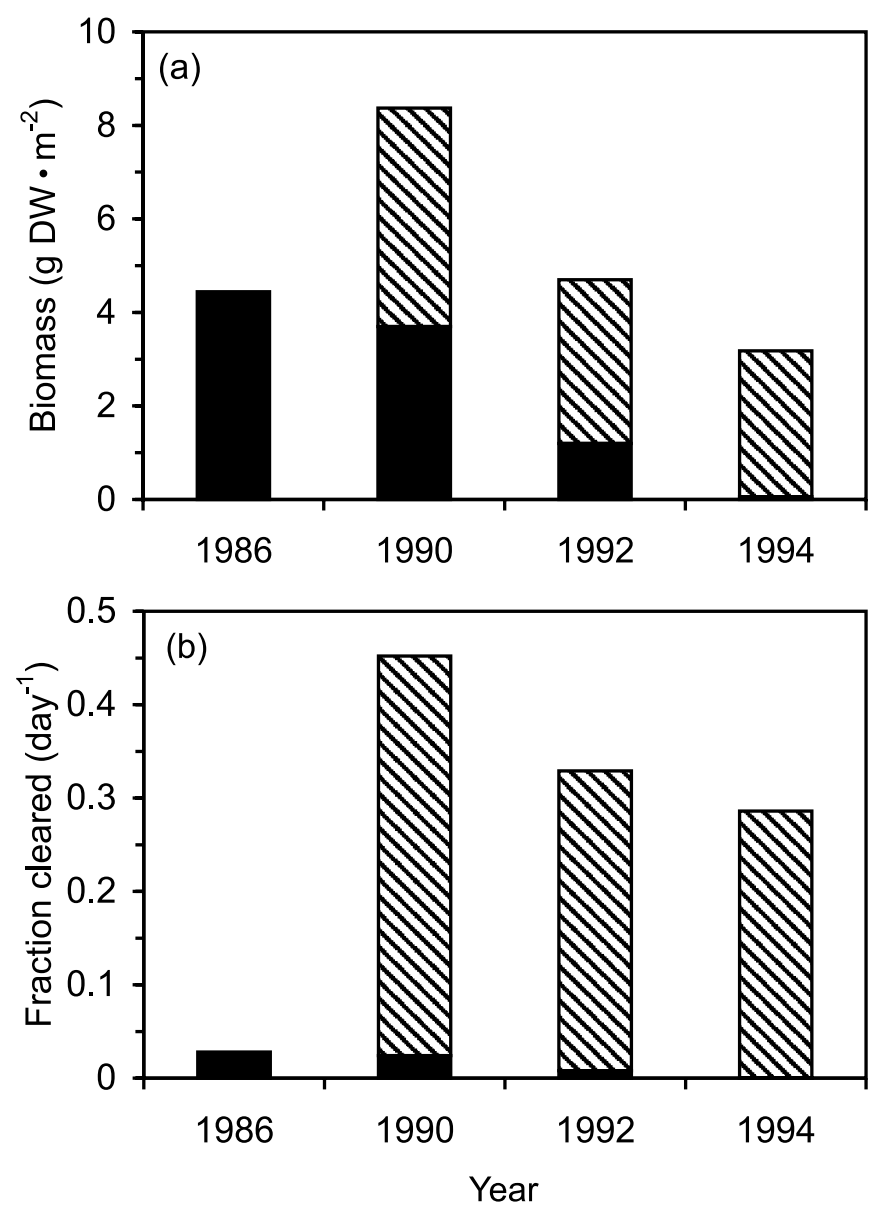

ciated with greater consumption of zooplankton and benthic invertebrate prey by young-of-year and adult yellow perch; however, young fish that benefitted from the increased visibility might have in turn suffered greater mortality from their predators (Mayer et al. 2000).

The Lake St. Clair ecosystem has greatly changed after the invasion by benthic Ponto-Caspian organisms. The change in fisheries appears consistent with the shift to a clear-water, macrophyte-dominated system caused by the zebra mussel and increased forage fishes in the form of round gobies. An obvious question is whether the clear-water phase will remain the dominant state (Scheffer 1989). The round gobies will be able to crop smaller mussels, but the larger mussels will remain to filter, assuming waterfowl feeding is not great enough to remove large individuals. The presence of the macrophytes themselves will remain a stabilizing influence by competing with algae for $\mathrm{P}$ and by stabilizing the sediments, which would be less likely to be resuspended and contribute to decreased water clarity and particle-associated $\mathrm{P}$ inputs. 


\section{Open Great Lakes environments with deep basins}

\section{Eastern Lake Erie}

The best information that we have for dreissenid biomass and impacts to a deep basin are for eastern Lake Erie. Makarewicz et al. (2000) observed that average chlorophyll $a$ concentration $\left(1.3 \mu \mathrm{g} \cdot \mathrm{L}^{-1}\right)$ in the eastern basin of Lake Erie during spring after dreissenids (1989-1993) was the same as that before dreissenids (1983-1988) and that summer concentration was not significantly lower $\left(2.0 \mu \mathrm{g} \cdot \mathrm{L}^{-1}\right)$ after vs. before mussels $\left(2.4 \mu \mathrm{g} \cdot \mathrm{L}^{-1}\right)$. Although chlorophyll $a$ did not change, SRP significantly increased from 2.4 before dreissenids to $4.6 \mu \mathrm{g} \cdot \mathrm{L}^{-1}$ after dreissenids. These chlorophyll $a$ concentrations belied intense interactions occurring in the "nearshore" plankton and benthic communities as well as changes to the deep benthos. The ranges of percent contribution to production for two shallow $(6 \mathrm{~m}$ and $9 \mathrm{~m})$ and one deep $(38 \mathrm{~m})$ station in the study of Johannsson et al. (2000) were 80-97\%, 2$9 \%$, and $1-12 \%$ for dreissenids, other benthos, and zooplankton, respectively. There was no decrease in biomass of other benthos in 1993 and 1994 relative to 1979, although Diporeia was not found at the deep station. Both chlorophyll $a$ and primary production were lower at these nearshore $(6 \mathrm{~m}$ and $9 \mathrm{~m})$ stations than would be predicted from regressions relating these variables to TP (Johannsson et al. 2000). This would be expected to decrease food available to zooplankton, and regression models that also accounted for planktivory suggested that zooplankton production in nearshore areas was greatly decreased by lowered primary production presumably driven by Dreissena filtering. This is consistent with FC $\left(0.17\right.$ day $\left.^{-1}\right)$ estimated in Table 1 for this oligotrophic basin, and in nearshore areas the impact would be much greater because of the inverse relation between FC and depth. Unfortunately, no direct comparisons of zooplankton biomass and production before and after Dreissena could be made.

However, in the offshore, deep-water $(30-60 \mathrm{~m})$ sites of the eastern basin, the biomass of deep-water fauna (dominated by Diporeia and oligochaetes) was 38\% lower in 1993 relative to 1979. Diporeia suffered the greatest loss, decreasing by $64 \%$ of its previous biomass (Dermott and Kerec 1997). As Dermott and Kerec (1997) and Dermott et al. (1998a) indicate, Dreissena bugensis, which were found at high numbers and biomass (35000 individuals $\cdot \mathrm{m}^{-2}$ and $10.9 \mathrm{~g} \mathrm{DW} \cdot \mathrm{m}^{-2}$, respectively) on the bottom, likely intercept a substantial fraction of settling material that would normally be destined for Diporeia (see above).

\section{Decline of Diporeia in Lake Michigan and Lake Ontario}

Massive declines of Diporeia in many areas of Lakes Michigan (Nalepa et al. 1998, 2000) and Ontario (Dermott 2001; Lozano et al. 2001) also have been attributed to competition with Dreissena for settling algae, particularly spring diatoms. However, Diporeia is declining in areas with no mussels, and high benthic inputs of diatoms during the spring bloom are still occurring in Lake Michigan (T. Nalepa, unpublished data). Dermott (2001) speculated that longshore current patterns carry water laden with algae past the mussels before it reaches the Diporeia in other areas. He also suggested that some other unknown Dreissena-related factor might be causing the problem. Quantifying the role of Dreissena in the decline of Diporeia can only be resolved with better estimates of Dreissena biomass, particle transport, and Diporeia ecology.

Diporeia is an important component of the food web in the hypolimnion of the Great Lakes, and the replacement of Diporeia by Dreissena, whether or not caused by Dreissena, has potentially serious consequences for Great Lakes fisheries (Fig. 8). Diporeia is an energy-rich (high lipid concentration) major food item of important forage fishes, such as bloaters (Coregonus hoyi), rainbow smelt (Osmerus mordax), slimy sculpins, and deepwater sculpins, and of important commercial and sport fishes, such as lake whitefish (Coregonus clupeaformis) and young lake trout (Salvelinus namaycush) (Owens and Weber 1995; Rand et al. 1995; Dermott et al. 1999). Dreissena is not eaten by many indigenous Great Lakes fishes, and the ones that have, such as lake whitefish and freshwater drum (Aplodinotus grunniens), have shown a decrease in condition factor after Dreissena became a major diet component (French and Bur 1996; Hoyle et al. 1999; Pothoven et al. 2001). The loss of Diporeia to some of these fishes, particularly those that can feed in the water column, could be alleviated somewhat by their switching to Mysis (Fig. 8). The Diporeia decline is thought to have been responsible for large declines of lake whitefish and slimy sculpins in eastern Lake Ontario (Hoyle et al. 1999; Lozano et al. 2001).

\section{Great Lakes dispersal and impacts- synthesis and conclusions}

\section{Comparison of dispersal patterns of Ponto-Caspian invaders in the Great Lakes}

The Lake St. Clair region-the corridor encompassing the St. Clair River, Lake St. Clair, and the Detroit River-has been an epicenter for the establishment of four of the six Ponto-Caspian species studied. The two exceptions were quagga mussel (first sighted in Lake Erie) and Cercopagis (Lake Ontario). All six Ponto-Caspian invaders were first identified in the lower Great Lakes (Lakes St. Clair, Erie, and Ontario). Why the Lake St. Clair region appears to be so favorable for Ponto-Caspian species is unknown. We can only speculate that the Lake St. Clair region environment closely matches donor regions on the Black and Caspian seas (e.g., Mills et al. 1996; Jude 2001; Makarewicz et al. 2001).

Examination of invader distributions from descriptions above and from more detailed maps (e.g., New York Sea Grant 2002) showed a combination of continuous, or natural, dispersal punctuated by discontinuous dispersal (operationally defined as large movements not explained by "natural" spread of the organism) for all Ponto-Caspian species. Continuous "downstream" or water-current-mediated dispersal would be expected for Cercopagis and Dreissena spp. during their planktonic stages and continuous upstream or downstream dispersal by swimming by Neogobius, Proterorhinus, and Echinogammarus, although the last, being small and a weak swimmer relative to fishes, would have a greater tendency to be transported downstream. Extreme examples of rapid, discontinuous dispersal include the zebra mussel, which appeared "upstream" in the Duluth area of Lake Superior and near Chicago and Green Bay in Lake Michigan approximately 2 years after its initial sighting in Lake St. Clair (New York 
Fig. 8. Impacts of dreissenids on the hypolimnetic food web of Lakes Michigan, Huron, and Ontario and the eastern basin of Lake Erie, showing the roles of Diporeia hoyi, Mysis relicta, and Dreissena spp. in the food web of the dominant forage fishes-bloater, alewife, and slimy and deepwater sculpins — and the commercially important lake whitefish. The food web shown most closely resembles that of Lakes Michigan and Huron; in Lake Lakes Erie and Ontario, the deep-chlorophyll layer is not as well developed, and Mysis is not as important or is lacking. In eastern Lake Erie, the rainbow smelt is the dominant pelagic forage fish. Thick arrows imply high prey selectivities for the indicated prey. Alewives, which also prey in the epilimnion (Fig. 5), prey in the upper hypolimnion, whereas bloaters feed at greater depths on both pelagic and benthic prey. The obligate benthivores, slimy and deepwater sculpins and lake whitefish, can feed on Mysis, when it is on the bottom. The dotted line with two arrowheads indicates potential competitive interactions between Dreissena and Diporeia.

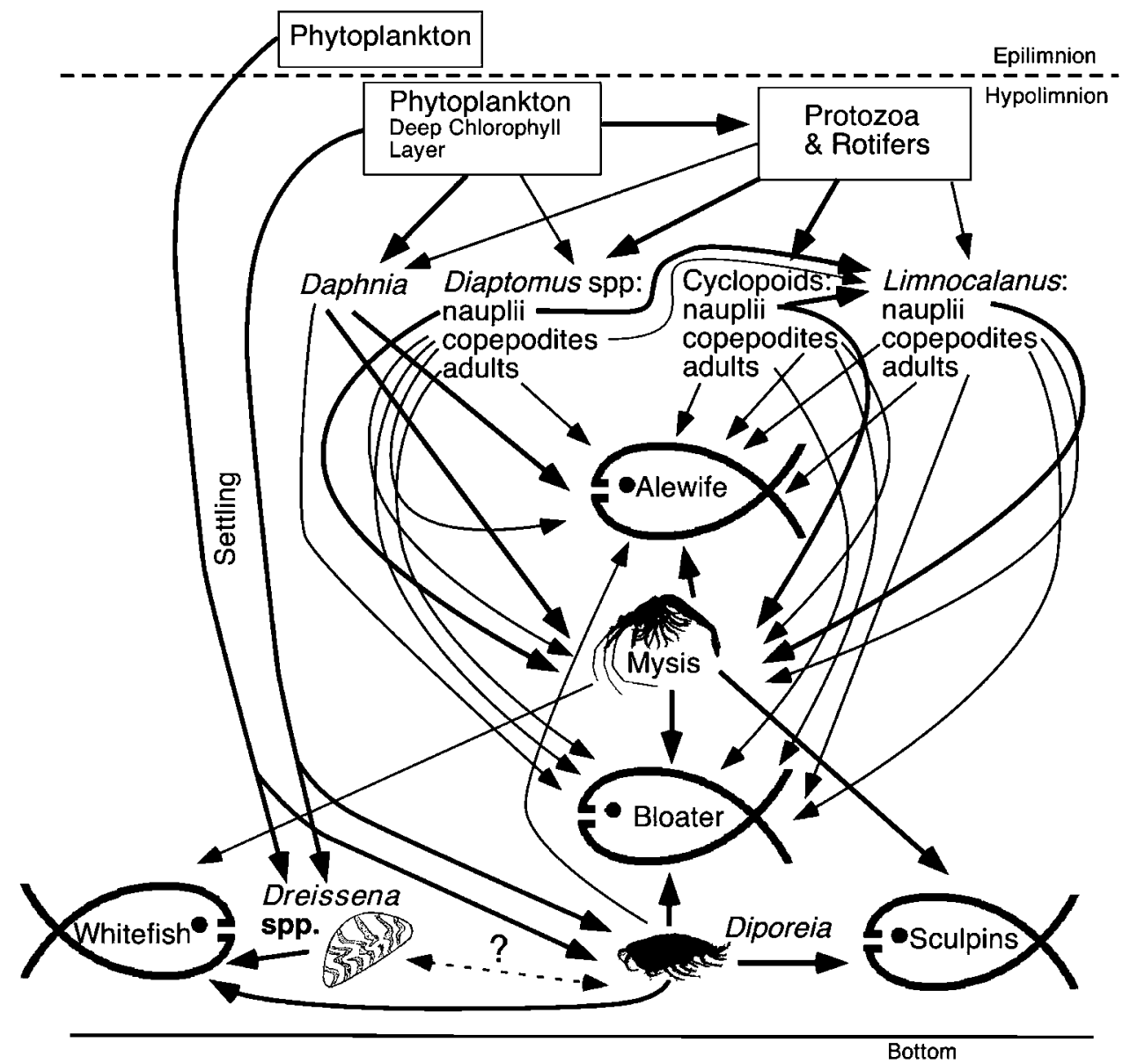

Sea Grant 2002), and Cercopagis, which appeared $800 \mathrm{~km}$ upstream in Lake Michigan within 1 year after discovery in Lake Ontario (see above). Although one could argue that discontinuous sightings could be a result of data gaps, we contend that discontinuous dispersal patterns are more likely the result of secondary mechanisms such as intra-lake ship transport. In the case of Cercopagis, it can be argued that there was a single introduction with interlake transport, because mitochondrial DNA analyses showed all Great Lakes populations to be of the same haplotype (T. Therriault and I. Grigorovich, University of Windsor, Windsor, Ont., personal communication).

\section{Impacts-case studies}

The zebra mussel quickly invaded hard substrates in bays and shallow waters $(<30 \mathrm{~m})$ of the Great Lakes except for the calcium-poor, cool waters of Lake Superior. We suspect, from the experience in Saginaw Bay, that some of these populations expanded beyond the carrying capacity of the envi- ronment and then settled down to equilibrium levels. In Long Point Bay, diving ducks may have initially controlled high densities of zebra mussels. The diving ducks greatly increased their use of Long Point Bay to feed on mussels during their migration. There is some question as to whether the ingestion of zebra mussels, which have high contaminant concentrations relative to other benthos, is affecting reproductive success of ducks. Zebra mussels more slowly colonized softer sediments by adhering to small sand grains and each other, as was observed for western Lake Erie; similar behavior is still occurring in Lake Michigan.

The cool-water-tolerant quagga mussel, the second dreissenid invader, first sighted as an "epilimnetic" morph, successfully competed with and replaced zebra mussels in some shallow areas $(<30 \mathrm{~m})$; it also extended onto soft sediments in deeper waters as a "profunda" morph in Lakes Erie and Ontario. Quagga populations quickly expanded into deep areas of Lake Erie. The ability of these dreissenids to colonize a variety of substrates and depths may mean that aggregate 
dreissenid densities will approach concentration limits dictated by primary production and nutritional quality of the phytoplankton as well as processes that affect delivery of food to the benthos rather than substrate limitation.

The high densities of dreissenids that occur in some Great Lakes and their intrinsically high filtering rates allowed them to clear a substantial fraction of phytoplankton growth and intercept a substantial fraction of particles settling to the deep benthos. In the shallow bays and basins and in Lake Erie as a whole, where most of the most dramatic changes and well-documented studies have occurred, there have been profound changes in ecosystem structure and function driven by the Ponto-Caspian benthic assemblage, particularly by zebra and quagga mussels. In Lake Erie, dreissenids have dominated invertebrate production. In systems where zebra mussel biomass and FC were large, substantial changes in ecosystem structure and function have occurred. The case studies, particularly the study of Lake St. Clair, demonstrated that ecological impacts are not just driven by Dreissena shunting energy from the pelagic to benthic realms. Autogenic ecosystem engineering, by providing substrate, and allogenic ecosystem engineering, by increasing light intensity to the benthos, had profound impacts on changing habitat conditions. Lake St. Clair was changed from a turbid, pelagic-dominated system to a clear-water macrophytedominated system that provided feeding and spawning habitat for yellow perch, smallmouth bass, and muskellunge, while habitat for walleye was lost. The round goby may play an important ecological role in these ecosystems serving as both a predator on zebra mussels and as a prey for fish.

Comparison of the Saginaw Bay and western Lake Erie ecosystems demonstrated the limits of zebra mussels acting as system stabilizers or eutrophication controllers (Herman and Scholten 1990) to control phytoplankton concentrations. These studies showed that in the spring, Dreissena were able to keep phytoplankton concentrations low relative to premussel concentration in two systems with different SRP concentrations, but in summer, they were not able to control algal abundance. The occurrence of Microcystis blooms in these two systems suggests that these blooms cannot be prevented or controlled by mussel filtering, but that the dreissenids themselves may contribute to formation of these blooms through selective rejection in pseudofeces. In addition to Microcystis blooms there were occasional problems with attached algae and macrophytes washing up on beaches.

Despite high FC values and high production of zebra mussels, densities of non-dreissenid benthic invertebrates-except for the extirpated unionids-remained the same in western Lake Erie and shallow areas of eastern Lake Erie. Also, valuable fish prey species like Hexagenia and Gammarus increased at least until 1993, the last time that this system was examined for all invertebrates. Is this just a transitional state?

Curiously, zooplankton biomass and production were only slightly lower in western Lake Erie after zebra mussel establishment, and growth rates of young fishes, which are dependent on zooplankton, did not decrease. We do not know enough about the ecology of these systems to say whether this is a transitional state. If it is stable, the zebra mussels were somehow not removing enough phytoplankton to affect zooplankton production or possibly their filtering and $\mathrm{PO}_{4}$ excretion selected for fast-growing, nutritious phytoplankton for zooplankton to graze. The proximity of the N:P ratios of the seston to the Redfield ratio and excretion of $\mathrm{N}$ and $\mathrm{P}$ near the Redfield ratio and relatively high SRP found in western Lake Erie are consistent with the mussels providing $\mathrm{PO}_{4}$ and selection, through grazing, for phytoplankton with rapid growth rates. This option is not available in the more P-limited environment of Saginaw Bay, where homeostatic excretion of $\mathrm{P}$ may further limit $\mathrm{P}$ availability.

The strong decline of Diporeia density that occurred in eastern Lake Erie and Lakes Michigan and Ontario may represent the energy shunted away from Diporeia to Dreissena. In deep, phytoplankton-dominated open-lake systems like the Great Lakes, Dreissena benefits some other members of the benthic community such as Gammarus and Echinogammarus in nearshore areas by providing substrate and food in the form of feces and pseudofeces. At the same time, however, Dreissena removes algae that normally would settle or be focused into transitional and profundal areas to be available to the oligochaete-sphaeriid-Diporeia complex. Diporeia may have been the first of the assemblage to suffer because of its use of freshly sedimented algae, whereas the others, especially the oligochaetes, use materials "stored" in the sediment. It is unfortunate there are not good data on dreissenid biomass to quantify their impact on Diporeia, or at least determine if the loss in Diporeia biomass is equal to the increase in Dreissena biomass. It is likely the native benthic fish community will suffer as result of the loss of Diporeia, because it is an energy-rich prey and because Dreissena is not a good alternative prey.

Round gobies, Echinogammarus, and Dreissena formed an "invasional meltdown" community in the Great Lakes with the zebra mussels facilitating expansion of its PontoCaspian associates in the Great Lakes (Ricciardi 2001). The aggressive $r$ strategist round gobies in particular benefitted because Dreissena is a favored prey that was not being utilized efficiently by native Great Lakes fishes. Based on the experience in Lake St. Clair, it seems likely that round gobies will become an important part of the Great Lakes food web. The high production and $r$ strategies of both zebra mussels and round gobies will greatly benefit piscivores that can utilize round gobies. Important concerns of round gobies relate to their potentially high contaminant load from feeding on mussels, the possibility that they would prey on trout eggs and fry on trout spawning reefs, and their effects on biodiversity through their competition with various species of sculpins.

\section{Lessons learned-the limits of generalization and of extrapolation}

Hypothesized general attributes of invasive aquatic species (Lodge 1993; Ricciardi and Rasmussen 1998), including $r$ strategy, wide environmental tolerance, mechanisms of rapid dispersal, genetic variability, phenotypic plasticity, commensal with human activities (ballast water transport) along with the concept of invasional meltdown (Ricciardi 2001) apply in general terms to explain the dispersal and success of these PontoCaspian species in the Great Lakes. All of these attributes apply to Dreissena (Ricciardi and Rasmussen 1998), and all but the tubenose goby and Echinogammarus are $r$ strategists; how- 
ever, Lodge (1993) noted the value of this intuitively attractive attribute is not supported by correlative analysis of a variety of terrestrial invaders. He cites inappropriate climate and predation as major causes of failure to become established. It is worth noting that Dreissena is protected from much predation during both its larval and adult stages by a shell, and Cercopagis is protected by a spine as well as production of resting egg banks. Both Echinogammarus and round gobies benefitted from facilitation by the zebra mussels.

Although dispersal rates differ greatly owing to differences in human facilitation, patterns of geographic dispersal of Ponto-Caspian invaders in the Laurentian Great Lakes are remarkably similar to those observed in Eurasia. As in Eurasia, the zebra mussel, Echinogammarus, round goby, and Cercopagis have all exhibited widespread and spontaneous expansion of their geographic range since their introduction to North American waters (e.g., Mills et al. 1996; Dermott et al. 1998b; Makarewicz et al. 2001). Conversely, both the quagga mussel and the tubenose goby have more limited range expansions in North America and Eurasia (Mills et al. 1996; Jude 2001). The quagga has expanded into new territories at a much slower rate than the zebra mussel, but where the quagga has invaded North American and eastern Eurasian waters, they have generally become the dominant dreissenid (Mills et al. 1996). This experience would suggest that quagga mussels might ultimately replace zebra mussels that are invading the deep areas of Lake Michigan. Invasion histories of the tubenose goby are also remarkably similar in both North America and Eurasia. Ironically, the tubenose goby is rare in its native habitat of the Black and Caspian seas (Jude 2001) and so far is scarce in the Laurentian Great Lakes (Jude 2001).

The hypothesized general attributes of invaders may be useful for describing which invader is successful, but they are not useful for specifying impacts. Even extrapolation of invader impacts from one system to another is difficult and requires detailed understanding of the invader and donor and receptor ecosystems. Some of the changes observed in the Great Lakes as a result of Ponto-Caspian invaders could have been predicted from documented changes in Europe (Karatayev et al. 1997). The knowledge that zebra mussel filtering can increase water clarity and that increased water clarity can shift a formerly plankton-dominated system to a macrophyte-dominated system could have been used to predict the shift to macrophytes in Lake St. Clair (Reeders and Bij de Vaate 1990; Karatayev et al. 1997). Likewise, the response of Long Point waterfowl to the increase in dreissenids makes sense in light of Dreissena and waterfowl interactions in Europe (Petrie and Knapton 1999). Also, the dominance of zebra mussel production and the benefit of zebra mussels to benthic invertebrates obtaining substrate and food from feces and pseudofeces in the Great Lakes have been seen in shallow systems in Eastern Europe (Karatayev et al. 1997).

Nevertheless, many ecological responses we care about in the Great Lakes were unique and strongly site and species specific. In Lake St. Clair, the fisheries response was site and species specific and could not have been predicted without intimate knowledge of the ecology of these fishes and the particular plants that would have increased with increasing light intensity. Likewise decimation of unionids could not have been predicted from the European experience. The promotion of Microcystis or other blue-green algal blooms have not been reported in Europe, perhaps because such blooms depend on the high mussel densities in large, wellmixed systems having certain nutrient conditions and high temperatures (Vanderploeg et al. 2001). Also, nutrient concentrations and $\mathrm{N}: \mathrm{P}$ ratios are important for affecting mussel biomass through their control of phytoplankton production and composition, and recycling by the mussels varies from site to site.

Food webs in large lakes such as the Great Lakes are very different from those of small lakes and rivers of Eurasia, and we have seen the difference among Great Lakes sites that are related to water depth. The decline of Diporeia has no parallel in the shallow lakes studied in Eastern Europe. We are not aware of any Dreissena-driven declines of Monoporeia affinis, a sister species of Diporeia, in the large, deep lakes of Europe or in the Baltic Sea. Likewise, where the deep chlorophyll layer intersects with the bottom in the transition areas of some Great Lakes may be an important habitat not seen in shallow or eutrophic lakes, where this feature does not occur.

Drawing conclusions from studies of Ponto-Caspian invaders in Europe for application to the Great Lakes will be even more difficult now that the Great Lakes have two species of Dreissena, a native fish fauna not well-adapted to feeding on mussels, and round gobies; whereas Europe has zebra mussels and a fish fauna well adapted to feeding on mussels, but no round gobies (Karatayev et al. 1997).

Finally, one of the most difficult aspects of this synthesis was to find long-term time series describing ecological events before and after establishment of each Ponto-Caspian invader. We need better information on how food webs operate in the Great Lakes - we did not fully understand them before the Ponto-Caspian invaders, and we certainly do not understand them now. Although we have historically emphasized pelagic systems, we are particularly ignorant of the benthic food web. We need to better understand the benthic food web as current and potential (Ricciardi and Rasmussen 1998) Ponto-Caspian invaders are poised to influence benthic-pelagic production processes in Great Lakes ecosystems in the future.

\section{Acknowledgements}

This is GLERL contribution number 1231, and CGLAS contribution number 623. We thank H.J. MacIsaac and D.F. Reid for organizing and providing travel to the ASLO 2000 preconference workshop on nonindigenous species, where this paper was presented. We appreciate the useful comments of two anonymous referees, and we thank the following colleagues for giving us access to unpublished data or submitted manuscripts: T.B. Bridgeman, R. Dermott, T. Granata, R.C. Haas, T.H. Johengen, C. Knight, S.J. Lozano, J.C. Makarewicz, H.J. MacIsaac, C.P. Madenjian, D.S. MacLennan, C. Mayer, D. Pratt, A. Ricciardi, O. Sarnelle, T. Therriault, R. Thoma, M.V. Thomas, and A.E. Wilson.

\section{References}

Arnott, D.L., and Vanni, M.J. 1996. Nitrogen and phosphorus recycling by the zebra mussel (Dreissena polymorpha) in the western basin of Lake Erie. Can. J. Fish. Aquat. Sci. 53: 646-659. 
Beeton, A.M., and Hageman, J., Jr. 2000. Changes in zooplankton populations in western Lake Erie after establishment of Dreissena polymorpha. Verh. Internat. Verein. Limnol. 27: 3798-3804.

Benoît, H.P., Johansson, O.E., Warner, D.M., Sprules, W.G., and Rudstam, L.G. 2002. Assessing the impact of a recent predatory invader: the population dynamics, vertical distribution, and potential prey of Cercopagis pengoi in Lake Ontario. Limnol. Oceanogr. 47: 626-635.

Bially, A., and MacIsaac, H.J. 2000. Fouling mussels (Dreissena spp.) colonize soft sediments in Lake Erie and facilitate benthic invertebrates. Freshwater Biol. 43: 85-97.

Branstrator, D.K., and Lehman, J.T. 1996. Evidence for predation of young-of-year alewife and bloater chub on Bythotrephes cederstroemi in Lake Michigan. J. Great Lakes Res. 22: 917-924.

Bridgeman, T.B., Fahnenstiel, G.L., Lang, G.A., and Nalepa, T.F. 1995. Zooplankton grazing during the zebra mussel (Dreissena polymorpha) colonization of Saginaw Bay, Lake Huron. J. Great Lakes Res. 21: 567-573.

Cabana, G., Tremblay, A., Kalff, J., and Rasmussen, J.B. 1994. Pelagic food chain structure in Ontario lakes: a determinant of mercury levels in lake trout (Salvelinus namaycush). Can. J. Fish. Aquat. Sci. 51: 381-389.

Charlebois, P.M., Raffenberg, M.J., and Dettmers, J.M. 2001. First occurrence of Cercopagis pengoi in Lake Michigan. J. Great Lakes Res. 27: 258-261.

Chotkowski, M.A, and Marsden, J.E. 1999. Round goby and mottled sculpin predation on lake trout eggs and fry: field predictions from laboratory experiments. J. Great Lakes Res. 25:26-35.

Claxton, W.T., Wilson, A.B., Mackie, G.L., and Boulding, E.G. 1998. A genetic and morphological comparison of shallow- and deepwater populations of the introduced dreissenid bivalve Dreissena bugensis. Can. J. Zool. 76: 1269-1276.

Custer, C.M., and Custer, T.W. 1997. Occurrence of zebra mussels in near-shore areas of western Lake Erie. J. Great Lakes Res. 23: $103-115$.

Dahl, J.A., Graham, D.M., Dermott, R., Johannsson, O.E., Millard, E.S., and Myles, D.D. 1995. Lake Erie 1993, western, westcentral, and eastern basins: changes in trophic status, and assessment of the abundance, biomass and production of the lower trophic levels. Can. Tech. Rep. Fish. Aquat. Sci. No. 2070.

Dermott, R. 2001. Sudden disappearance of the amphipod Diporeia from eastern Lake Ontario, 1993-1995. J. Great Lakes Res. 27: 423-433.

Dermott, R., and Kerec, D. 1997. Changes in the deepwater benthos of eastern Lake Erie since the invasion of Dreissena: 1979-1993. Can. J. Fish. Aquat. Sci. 54: 922-930.

Dermott, R., Munawar, M., and Lorimer, J. 1998a. Submersible confirmation of the profuse abundance of Dreissena on sediments in Lake Erie: implications to food web. Verh. Int. Verein. Limnol. 26: 2044-2047.

Dermott, R., Witt, J., Um, Y.M., and González, M. 1998b. Distribution of the Ponto-Caspian amphipod Echinogammarus ischnus in the Great Lakes and replacement of native Gammarus fasciatus. J. Great Lakes Res. 24: 442-452.

Dermott, R., Munawar, M., Witzel, L., and Ryan, P.A. 1999. An assessment of food-web changes in eastern Lake Erie: impact of Dreissena spp. and phosphorous management on rainbow smelt, Osmerus mordax. In State of Lake Erie-past, present, and future (SOLE). Edited by M. Munawar, T. Edsall, and I.F. Munawar. Backhuys Publishers, Leiden, The Netherlands. pp. 367-385.

Dubs, D.O.L., and Corkum, L.D. 1996. Behavioral interactions between round gobies (Neogobius melanostomus) and mottled sculpins (Cottus bairdi). J. Great Lakes Res. 22: 838-845.
Edsall, T.A., Madenjian, C.P., and Manny, B.A. 1999. Burrowing mayflies in Lake Erie-a review. In State of Lake Erie-past, present, and future (SOLE). Edited by M. Munawar, T. Edsall, and I.F. Munawar. Backhuys Publishers, Leiden, The Netherlands. pp. 219-231.

Fahnenstiel, G.L., Bridgeman, T.B., Lang, G.A., McCormick, M.J., and Nalepa, T.F. 1995. Phytoplankton productivity in Saginaw Bay, Lake Huron: effects of zebra mussel (Dreissena polymorpha) colonization. J. Great Lakes Res. 21: 465-475.

Francis, J.T., Robillard, S.R., and Marsden, J.E. 1996. Yellow perch management in Lake Michigan: a multi-jurisdictional challenge. Fisheries (Bethesda), 21: 18-20.

French, J.R.P., III. 1993. How well can fishes prey on zebra mussels in eastern North America? Fisheries (Bethesda), 18: 13-19.

French, J.R.P., III, and Bur, M.T. 1996. The effect of zebra mussel consumption on growth of freshwater drum in Lake Erie. J. Freshwater Ecol. 11: 283-289.

French, J.R.P., III, and Jude, D.J. 2001. Diets and diet overlap of nonindigenous gobies and small benthic native fishes co-inhabiting the St. Clair River, Michigan. J. Great Lakes Res. 27: 300-311.

Gardner, W.S., Eadie, B.J., Chandler, J.F., Parrish, C.C., and Malczyk, J.M. 1989. Mass flux and "nutritional composition" of settling epilimnetic particles in Lake Michigan. Can. J. Fish. Aquat. Sci. 46: $1118-1124$.

Garton, D.W., and Haag, W.R. 1992. Seasonal reproductive cycles and settlement patterns of Dreissena polymorpha in western Lake Erie. In Zebra mussels: biology, impacts, and control. Edited by T.F. Nalepa and D. Schloesser. Lewis Publishers, Boca Raton. pp. 111-128.

Hamilton, D.J., and Ankney, C.D. 1994. Consumption of zebra mussels Dreissena polymorpha by diving ducks in Lakes Erie and St. Clair. Wildfowl, 45: 159-166.

Hanson, J.M., and Peters, R.H. 1984. Empirical prediction of crustacean zooplankton biomass and profundal macrobenthos biomass in Lakes. Can. J. Fish. Aquat. Sci. 41: 439-445.

Hecky, R.E., Campbell, P., and Hendzel, L.L. 1993. The stoichiometry of carbon, nitrogen, and phosphorus in particulate matter of lakes and oceans. Limnol. Oceanogr. 38: 709-724.

Herman, M.J., and Scholten, H. 1990. Can suspension feeders stabilize estuarine ecosystems? In Trophic relationships in the marine environment. Edited by M. Barnes and R.N. Gibson. Aberdeen University Press, Aberdeen, U.K. pp. 104-116.

Hoyle, J.A., Schaner, T., Casselman, J.M., and Dermott, R. 1999. Changes in lake whitefish (Coregonus clupeaformis) stocks in eastern Lake Ontario following Dreissena mussel invasion. Great Lakes Res. Rev. 4: 5-10.

Idrisi, N., Mills, E.L., Rudstam, L.G., and Stewart, D.J. 2001. Impact of zebra mussels (Dreissena polymorpha) on the pelagic trophic levels of Oneida Lake, New York. Can. J. Fish. Aquat. Sci. 58: 1430-1441.

Janssen, J., and Jude, D. 2001. Recruitment failure of mottled sculpin Cottus bairdi in southern Lake Michigan induced by the newly introduced round goby Neogobius melanostomus. J. Great Lakes Res. 27: 319-328.

Johannsson, O., Dermott, R., Graham, D.M., Dahl, J.A., Millard, S.E., Myles, D.D., and LeBlanc, J. 2000. Benthic and pelagic secondary production in Lake Erie after the invasion of Dreissena spp. with implications for fish production. J. Great Lakes Res. 26: 31-54.

Johengen, T.H., Nalepa, T.F., Fahnenstiel, G.L., and Goudy, G. 1995. Nutrient changes in Saginaw Bay, Lake Huron, after the establishment of the zebra mussel, Dreissena polymorpha. J. Great Lakes Res. 21: 449-465. 
Johengen, T.H., Nalepa, T.F., Lang, G.A, Fanslow, D.L., Vanderploeg, H.A., and Agy, M.A. 2000. Physical and chemical variables of Saginaw Bay, Lake Huron, in 1994-1996. NOAA Tech. Memo. GLERL-115.

Jones, C.G., Lawton, J.H., and Shachak, M. 1997. Positive and negative effects of organisms as physical ecosystem engineers. Ecology, 78: 1946-1957.

Jude, D.J. 2001. Round and tubenose gobies: 10 years with the latest Great Lakes phantom menace. Dreissena, 11(4): 1-14.

Karatayev, A.Y., Burlakova, L.E., and Padilla, D.K. 1997. The effects of Dreissena polymorpha (Pallas) invasion on aquatic communities in Eastern Europe. J. Shellfish Res. 16: 187-203.

Knapton, R.W., and Petrie, S.A. 1999. Changes in distribution and abundance of submerged macrophytes in the inner bay at Long Point, Lake Erie: implications for forging waterfowl. J. Great Lakes Res. 25: 783-798.

Kryger, J., and Riisgård, H.U. 1988. Filtration rate capacities in 6 species of European freshwater bivalves. Oecologia, 77: 34-38.

Kuhns, L.A., and Berg, M.B. 1999. Benthic invertebrate community responses to round goby (Neogobius melanostomus) and zebra mussel (Dreissena polymorpha) invasion in Lake Michigan. J. Great Lakes Res. 25: 910-917.

Lavrentyev, P.J., Gardner, W.S., Cavaletto, J.F., and Beaver, J.R. 1995. Effects of the zebra mussel (Dreissena polymorpha Pallas) on protozoa and phytoplankton from Saginaw Bay, Lake Huron. J. Great Lakes Res. 21: 545-557.

Lehman, J.T., and Cáceres, C.E. 1993. Food-web responses to species invasion by a predatory invertebrate: Bythotrephes in Lake Michigan. Limnol. Oceanogr. 38: 879-891.

Liebig, J.R., and Vanderploeg, H.A. 1995. Vulnerability of Dreissena polymorpha larvae to predation by Great Lakes calanoid copepods: the importance of the bivalve shell. J. Great Lakes Res. 21: 353-358.

Lodge, D.M. 1993. Biological invasions: lessons for ecology. Trends Ecol. Evol. 8: 133-137.

Lowe, R.L., and Pillsbury, R.W. 1995. Shifts in benthic algal community structure and function following the appearance of zebra mussels (Dreissena polymorpha) in Saginaw Bay, Lake Huron. J. Great Lakes Res. 21: 558-566.

Lozano, S.J., Scharold, J.V., and Nalepa, T.F. 2001. Recent declines in benthic macroinvertebrate densities in Lake Ontario. Can. J. Fish. Aquat. Sci. 58: 518-529.

MacArthur, R.H., and Wilson, E.O. 1967. The theory of island biogeography. Princeton University Press, Princeton, N.J.

MacIsaac, H.J., Sprules, W.G., and Leach, J.H. 1991. Ingestion of small-bodied zooplankton by zebra mussels (Dreissena polymorpha): can cannibalism on larvae influence population dynamics? Can J. Fish. Aquat. Sci. 48: 2051-2060.

MacIsaac, H.J., Sprules, W.G., Johannsson, O.E., and Leach, J.H. 1992. Filtering impacts of larval and sessile zebra mussel (Dreissena polymorpha) in western Lake Erie. Oecologia, 92: 30-39.

MacIsaac, H.J., Lonnee, C.J., and Leach, J.H. 1995. Suppression of microzooplankton by zebra mussels: the importance of mussel size. Freshwater Biol. 34: 379-387.

Makarewicz, J.C., Bertram, P., and Lewis, T.W. 2000. Chemistry of offshore surface waters of Lake Erie: pre- and post-Dreissena introduction (1983-1993). J. Great Lakes Res. 26: 82-93.

Makarewicz, J.C., Grigorovich, I.A., Mills, E., Damaske, E., Cristescu, M.E., Pearsall, W., LaVoie, M.J., Keats, R., Rudstam, L., Hebert, P., Halbritter, H., Kelly, T., Matkovich, C., and MacIsaac, H.J. 2001. Distribution, fecundity, genetics, and dispersal of Cercopagis pengoi (Crustacea, Cladocera) - a new exotic zooplankter in the Great Lakes basin. J. Great Lakes Res. 27: 19-32.

Mayer, C.M., Van De Valk, A.J., Forney, J.L., Rudstam, L.G., and Mills, E.L. 2000. Response of yellow perch (Perca flavascens) in
Oneida Lake, New York, to the establishment of zebra mussels (Dreissena polymorpha). Can. J. Fish. Aquat. Sci. 57: 742-754.

Mellina, E., and Rasmussen, J.B. 1994. Patterns in the distribution and abundance of zebra mussel (Dreissena polymorpha) in rivers and lakes in relation to substrate and other physicochemical factors. Can. J. Fish. Aquat. Sci. 51: 1024-1036.

Mills, E.L., O'Gorman, R., DeGisi, J., Heberger, R.F., and House, R.A. 1992. Food of the alewife (Alosa pseudoharengus) in Lake Ontario before and after the establishment of Bythotrephes cederstroemi. Can. J. Fish. Aquat. Sci. 49: 2009-2019.

Mills, E.L., Leach, J.H., Carlton, J.T., and Secor, C.L. 1993. Exotic species in the Great Lakes: a history of biotic crisis and anthropogenic introductions. J. Great Lakes Res. 19:1-54.

Mills, E.L., Rosenberg, G., Spidle, A.P., Ludyanskiy, M., Pligin, Y., and May, B. 1996. A review of the biology and ecology of the quagga mussel (Dreissena bugensis), a second species of freshwater dreissenid introduced to North America. Am. Zool. 36:271-286.

Mills, E.L., Chrisman, J.R., Baldwin, B., Owens, R.W., O'Gorman, R., Howell, T., Roseman, E.F., and Raths, M.K. 1999. Changes in the dreissenid community in the lower Great Lakes with emphasis on southern Lake Ontario. J. Great Lakes Res. 25: 187-197.

Nalepa, T.F., Fahnenstiel, G.L., McCormick, M.J., Johengen, T.H., Lang, G.A., Cavaletto, J.F., and Goudy, G. 1996a. Physical and chemical variables of Saginaw Bay, Lake Huron, in 1991-1993. NOAA Tech. Mem. ERL GLERL-91.

Nalepa, T.F., Hartson, D.J., Gostenik, G.W., Fanslow, D.L., and Lang, G.A. 1996b. Changes in the freshwater mussel community of Lake St. Clair: from Unionidae to Dreissena polymorpha in eight years. J. Great Lakes Res. 22: 354-369.

Nalepa, T.F., Hartson, D.J., Fanslow, D.L., Lang, G.A., and Lozano, S.J. 1998. Decline of benthic macroinvertebrate populations in southern Lake Michigan, 1980-1993. Can. J. Fish. Aquat. Sci. 55: 2402-2413.

Nalepa, T.F., Fahnenstiel, G.L., and Johengen, T.H. 1999. Impacts of the zebra mussel (Dreissena polymorpha) on water quality: a case study of Saginaw Bay, Lake Huron. In Nonindigenous freshwater organisms: vectors, biology, and impacts. Edited by R. Claudi and J.H. Leach. Lewis Publishers, Boca Raton. pp. 255-271.

Nalepa, T.F., Hartson, D.J., Buchanan, J., Cavaletto, J.F., Lang, G.A., and Lozano, S.J. 2000. Spatial variation in density, mean size and physiology condition of the holarctic amphipod Diporeia spp. in Lake Michigan. Freshwater Biol. 43: 107-119.

Nalepa, T.F., Schloesser, D.W., Pothoven, S.A., Hondorp, D.W., Fanslow, D.L., Tuchman, M.L., and Fleisher, G.W. 2001. First finding of Echinogammarus ischnus and the mussel Dreissena bugensis in Lake Michigan. J. Great Lakes Res. 27: 384-391.

New York Sea Grant. 2002. National Aquatic Nuisance Species Clearinghouse (maps). Available online (http://cce.cornell.edu/ aquaticinvaders/nan_maps.cfm?function $=$ ).

Nichols, S.J., and Wilcox, D.A. 1997. Burrowing saves Lake Erie clams. Nature (London), 389: 921.

Ojaveer, H., Simm, M., Lankov, A., and Lumberg, A. 2000. Consequences of invasion of a predatory cladoceran. ICES J. Mar. Sci. CM 2000/U:16.

Owens, R.W., and Weber, P.G. 1995. Predation on Mysis relicta by slimy sculpins (Cottus cognatus) in southern Lake Ontario. J. Great Lakes Res. 21: 275-283.

Pace, M.L., Findlay, W.E.G., and Fischer, D. 1998. Effects of an invasive bivalve on the zooplankton community of the Hudson River. Freshwater Biol. 39: 103-116.

Petrie, S.A., and Knapton, R.W. 1999. Rapid increase and subsequent decline of zebra and quagga mussels in Long Point Bay, 
Lake Erie: possible influence of waterfowl predation. J. Great Lakes Res. 25: 772-782.

Pothoven, S.A., Nalepa, T.F., Schneeberger, P.J., and Brandt, S.B. 2001. Changes in diet and body condition of lake whitefish in southern Lake Michigan associated with changes in benthos. N. Am. J. Fish. Manag. 21: 876-883.

Rand, P.S., Stewart, D.J., Lantry, B.F., Rudstam, L.G., Johannsson, O.E., Goyke, A.P., Brandt, S.B., O'Gorman, R., and Eck, G.W. 1995. Effect of lake-wide planktivory by the pelagic prey fish community in Lakes Michigan and Ontario. Can. J. Fish. Aquat. Sci. 52: 1546-1563.

Ray, W.J., and Corkum, L.D. 1997. Predation of zebra mussels by round gobies, Neogobius melanostomus. Environ. Biol. Fishes, 50: $267-273$.

Reeders, H.H., and Bij de Vaate, A. 1990. Zebra mussels (Dreissena polymorpha): a new perspective for water quality management. Hydrobiologia, 200/201: 437-450.

Ricciardi, A. 2001. Facilitative interactions among aquatic invaders: is an "invasional meltdown" occurring in the Great Lakes? Can. J. Fish. Aquat. Sci. 58: 2513-2525.

Ricciardi, A., and Rasmussen, J.B. 1998. Predicting the identity and impact of future biological invaders: a priority for aquatic resource management. Can. J. Fish. Aquat. Sci. 55: 1759-1765.

Ricciardi, A., Neves, R., and Rasmussen, J.B. 1998. Impending extinctions of North American freshwater mussels (Unionoida) following the zebra mussel (Dreissena polymorpha) invasion. J. Animal Ecol. 67: 613-619.

Rivier, I.K. 1998. The predatory Cladocera (Onychopoda: Podonidae, Polyphemidae, Cercopagidae) and Leptodorida of the world. Backhuys Publishing, Leiden, The Netherlands.

Roditi, H.A., Strayer, D.L., and Findlay, S.E.G. 1997. Characteristics of zebra mussel (Dreissena polymorpha) biodeposits in a tidal freshwater estuary. Arch. Hydrobiol. 140: 207-219.

Roe, S.L., and MacIsaac, H.J. 1997. Deepwater population structure and reproductive state of quagga mussels (Dreissena bugensis) in Lake Erie. Can. J. Fish. Aquat. Sci. 54: 2428-2433.

Ryan, P.A., Witzel, L.D., Paine, J., Freeman, M., Hardy, M., Scholten, S., Sztramko, L., and MacGregor, R. 1999. Recent trends in fish populations in eastern Lake Erie in relation to changing lake trophic state and food web. In State of Lake Erie - past, present, and future (SOLE). Edited by M. Munawar, T. Edsall, and I.F. Munawar. Backhuys Publishers, Leiden, The Netherlands. pp. 241-289.

Scavia, D., and Fahnenstiel, G.F. 1987. Dynamics of Lake Michigan phytoplankton: mechanisms controlling epilimnetic communities. J. Great Lakes Res. 13: 103-120.

Scheffer, M. 1989. Alternative stable states in eutrophic, shallow fresh water systems: a minimal model. Hydrobiol. Bull. 23: 73-84.

Schloesser, D.W., Nalepa, T.F., and Mackie, G.L. 1996. Zebra mussel infestation of unionid bivalves (Unionidae) in North America. Am. Zool. 36: 300-310.

Schloesser, D.W., Smithee, R.D., Longton, G.D., and Kovalak, W.P. 1997. Zebra mussel induced mortality of unionids in firm substrate of western Lake Erie and a habitat for survival. Am. Malacol. Bull. 14: 67-74.
Schulz, K.L., and Yurista, P.M. 1999. Implications of an invertebrate predator's (Bythotrephes cederstroemi) atypical effects on a pelagic zooplankton. Hydrobiologia, 380: 179-193.

Skubinna, J.P., Coon, T.G., and Batterson, T.R. 1995. Increased abundance and depth of submersed macrophytes in response to decreased turbidity in Saginaw Bay, Lake Huron. J. Great Lakes Res. 21: 476-488.

Smith, V.H. 1982. The nitrogen and phosphorus dependence of algal biomass in lakes: an empirical and theoretical analysis. Limnol. Oceanogr. 27: 1101-1112.

Stañczykowska, A., and Planter, M. 1985. Factors affecting nutrient budget in Lakes of the R. Jorka watershed (Masurian Lakeland, Poland). X. Role of the mussel Dreissena polymorpha (PALL.) in $\mathrm{N}$ and $\mathrm{P}$ cycles in a lake ecosystem. Ekol. Pol. 33: 345-356.

Sterner, R.W., Elser, J.J., and Hessen, D.O. 1992. Stoichiometric relationships among producers, consumers and nutrient cycling in pelagic ecosystems. Biogeochemistry, 17: 49-67.

Sterner, R.W., Elser, J.J., Fee, E.J., Guildford, S.J., and Chrzanowski, T.H. 1997. The light : nutrient ratio in lakes: the balance of and energy and materials affects ecosystem structure and process. Am. Nat. 150: 663-684.

Stewart, T.W., Miner, J.G., and Lowe, R.L. 1998. Macroinvertebrate communities on hard substrates in western Lake Erie: structuring effects of Dreissena. J. Great Lakes Res. 24: 868-879.

Strayer, D.L. 1999. Effects of alien species on freshwater mollusks in North America. J. North Am. Benthol. Soc. 18: 74-98.

Trometer, E.S., and Busch, W.-D.N. 1999. Changes in age-0 fish growth and abundance following the introduction of zebra mussels Dreissena polymorpha in the western basin of Lake Erie. N. Am. J. Fish. Manag. 19: 604-609.

U.S. Geological Survey. 2002. Nonindigenous fish distribution information. Available at http://nas.er.usgs.gov/fishes/fisheslist.htm.

Vanderploeg, H.A., Liebig, J.R., and Omair, M. 1993. Bythotrephes predation on Great Lakes' zooplankton measured by an in situ method: implications for community structure. Arch. Hydrobiol. 127: $1-8$.

Vanderploeg, H.A., Liebig, J.R., and Nalepa, T.F. 1995. From picoplankton to microplankton: temperature driven filtration by the unionid bivalve Lampsilis radiata siliquoidea in Lake St. Clair. Can. J. Fish. Aquat. Sci. 52: 63-74.

Vanderploeg, H.A., Liebig, J.R., Carmichael, W.W., Agy, M.A., Johengen, T.H., Fahnenstiel, G.F., and Nalepa, T.F. 2001. Zebra mussel (Dreissena polymorpha) selective filtration promoted toxic Microcystis blooms in Saginaw Bay (Lake Huron) and Lake Erie. Can. J. Fish. Aquat. Sci. 58: 1208-1221.

Wilson, A.E., and Sarnelle, O. 2002. Relationship between zebra mussel biomass and total phosphorus in European and North American lakes. Arch. Hydrobiol. 153: 339-351.

Witt, J.D.S., Hebert, P.D.N., and Morton, W.B. 1997. Echinogammarus ischnus: another crustacean invader in the Laurentian Great Lakes basin. Can. J. Fish. Aquat. Sci. 54: 264-268.

Yurista, P.M., and Schulz, K.L. 1995. Bioenergetic analysis of prey consumption by Bythotrephes in Lake Michigan. Can J. Fish. Aquat. Sci. 52: 141-150. 